\title{
LONGITUDES AND LATITUDES
}

\author{
A THESIS \\ Presented to \\ THE FACULTY OF THE GRADUATE SCHOOL \\ AT THE UNIVERSITY OF MISSOURI-COLUMBIA
}

In partial fulfillment

Of the requirements for the degree

MASTERS OF FINE ARTS

By

S. CHARLES THOMPSON

J BRETT GILL, THESIS SUPERVISOR

MAY 2014 
The undersigned, appointed by the dean of the Graduate School, have examined the thesis entitled

\section{LONGITUDES AND LATITUDES}

Presented by S. Charles Thompson,

Candidate for the degree Masters of Fine Art, and hereby certify that, in their opinion, it is worthy of acceptance.

Professor J Brett Grill

Dr. Heather Carver

Professor Jo Stealey 


\section{ACKNOWLEDGEMENTS}

To everyone who has supported me I would like to say thank you. I am appreciative of Brett Grill, Dr. Heather Carver and Jo Stealey for their help in the process of writing this thesis. They have dedicated their time, focus and energy to my project, but more importantly they do the same for other students and their respective programs. Thanks to office staff Brenda Warren for helping to file paperwork, Alan Toigo and Ferrie Craighead for helping in so many ways. Also, I would like to extend thanks to Eric Sweet and Chris Daniggelis for telling me things I did not want to hear when I needed to hear them. To all, I am forever grateful.

To fellow graduate students Eric Norby, Matt Rahner and Ron Thompson, siblings Izzy and Pat, your friendship has and will always be welcomed. To Jimmy and Sara Thompson, you are the best parents anyone could ask for. Thank you for sticking with me through this process of selfdiscovery. Thank you to my daughter Eloise for always wanting to play, and to Kate for being a wonderful partner and mother. I am forever grateful to Chris Douglas and Ryan Creutz for countless discussions on the meaning of life. 


\section{TABLE OF CONTENTS}

Acknowledgments................................ii

List of Illustrations............................... iv

Abstract.........................................

Part 1: Introduction..................................1

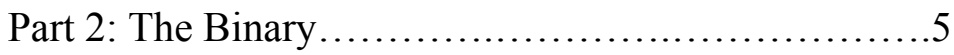

Part 3: Immortality Narratives.......................6

Part 4: Presence/Absence...........................10

Part 5: Trompe 1'oeil..............................14

Part 6: Minimal Art..................................21

Part 7: Materiality/Illusion..........................25

Part 8: The Index...............................27

Part 9: Longitudes and Latitudes....................29

Illustrations...................................... 31

Bibliography.....................................54 


\section{LIST OF ILLUSTRATIONS}

Figure

1 - S. Charles Thompson, Above Mt. Fuji ,2014.....................8

2 - S. Charles Thompson, Atop Mt. Fuji, 2014.....................8

3 - S. Charles Thompson, Centralia, Mo. \#1, 2014....................10

4 - S. Charles Thompson, Centralia, Mo. \#2, 2014........ ...........10

5 - S. Charles Thompson, Centralia, Pa., 2014....................10

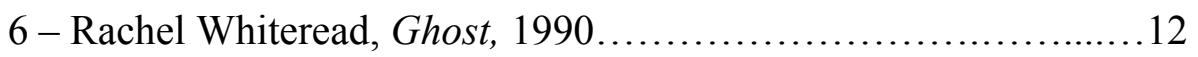

7 - Rachel Whiteread, House, 1993-4............................12

8 - William Harnett, Faithful Colt, 1890.........................16

9 - S. Charles Thompson, SHIFT I, 2014......................19

10 - S. Charles Thompson, AMID I, 2014.......................19

11 - Frank Stella, The Marriage of Reason and Squalor II, 1959....23 


\begin{abstract}
The fear of being forgotten provokes the human race to obtain illusions of immortality. Immortality is sought through the establishment of cultural legacy, granting the opportunity to exist beyond death. After one dies the body is consigned to a grave, their name continues to be recycled in the purgatory that cultural legacy provides.

In this project the museum is the artist's purgatory. An artist's cultural legacy is obtained through the embrace of the museum during his/her life. It is here that their name and work recycles, granting them immortality.

This body of work explores presence/absence, materiality/illusion and handedness/unhandedness and how they relate to cultural legacy. It establishes a central location between binary oppositions. It is in this central location between binary oppositions that I struggle with how to make a mark, be remembered and establish a legacy with a skillset directed at removing the hand. Navigating between the characteristics of Minimal Art and Trompe l'oeil painting, the work is neither completely material nor illusionary. The inability to reduce the work to either materiality or illusion creates a liminal state in which to contemplate the illusion of immortality. Through the veil of temporal materials, we peer through to the undefined. The work is presented in a state of permanent impermanence where the only constant is change.
\end{abstract}




\section{Part 1: Introduction}

The Way that can be articulately described is not the Unchanging Way.

The name that can be said out loud is not the Unchanging Name.

With your mouth unopened, and things left undefined, you stand at the beginning of the universe.

Make definitions, and you are the measure of all creation.

Thus, being forever without desire, you look deeply into the transcendent.

By constantly harboring desire, your vision is beset by all the things around you.

These two enter the world alike,

but their names are different.

Alike, they are called profound and remote.

Profound and remote and again more so:

This is the gate to all mysteries.

--Tao Te Ching

Canto I

The Book of The Way ${ }^{1}$

1. Tzu, Lao. Tao Te Ching: An All-New Translation. Translated by William Scott Wilson. Kodanasha International. Tokyo. 2010. Page 49 


\section{White Field}

It is like standing beyond

a snowfield with a single

set of footprints across it

and you say, Those prints are mine

because no one else has ever been here.

All day the snow comes down, all day you tell yourself what you feel,

but you remain in that place

beyond the snowfield.

Is there better proof

of your presence than

this open field, where you stand

now looking back across the white

expanse that is once more new to you?

As snow fills the places

where you must have walked,

you start back to where you began,

that place you again prepare to leave,

alone and warm, again intact, starting out.

--Daniel Halpern $1979^{2}$

2. Halpern, Daniel. Poetry. White Field. "The New Yorker". December $17^{\text {th }}, 1979$. Page 50 
White Field by Daniel Halpern was published in the December $17^{\text {th }}$ issue of The New Yorker, 1979. This poem suggests confusion between the presence of a footprint in snow and its opposite, absence. This idea seemed to evoke the opening lines of the Tao Te Ching, the first Dao text, which is quoted above. The inability to define our geographical location in the expanse of snow suggests the Dao belief, that the undefined is the beginning of the universe. ${ }^{3}$ To define something makes you the measure of creation. However, to define something means to acknowledge that it is in relationship to something else. Good is only definable in terms of what is bad and a mark is understood in terms of what has been unmarked. It is here, standing with an expanse of untouched snow in front of us, that the undefined and the defined will be separated.

As an artist, my skillset comes from a tradition of automotive restoration where the hand of the craftsman is not visible when the project is finished. From this experience I understand that the finer the craftsmanship, the less traces of human touch are left behind. The body panels of the car during restoration are meticulously sanded smooth and painted to look as though they have not been touched. I have always made things, but in the process removed my hand from them.

The body of work in this thesis exhibition titled, Longitudes and Latitudes, is a visual display of the challenge of introducing and expressive hand into a skillset rooted in rendering the hand absent. The work explores

3. Tzu, Lao. Tao Te Chng: An All-New Translation. Translated by William Scott Wilson. Kodanasha International. Tokyo. 2010. Page 49 
Trompe 1'oeil painting and Minimal art as modes of making that require the removal of the hand to achieve their desired result. These modes of making, like automotive restoration, require fine craftsmanship. As I explore the relationship between an expressive hand and the erasure of the hand through fine craftsmanship, binary oppositions such as Materiality/Illusion and Presence/Absence become confused. This confusion allows the work to remain between the handedness of my mark and the unhandedness of fine craftsmanship, presenting yet another binary opposition.

The materials used to make this body of work are impermanent. Latex paint, unprotected wood and masking tape were all chosen for this reason. The latex paint used in this project has a flat finish and will pick up marks if touched. The lack of protection on the wood leaves it open to accepting the oils of the hand and the residues of physical interactions such as scuffs and scratches. Masking tape is crucial to this work. It functions as a physical mask, between the image and the viewer, but not a visual mask. The transparency of the tape when applied over an image leaves the viewer feeling as though he/she is always peering through to an undefined ambiguous landscape. The tape lends a misty atmospheric quality to the work.. The choice in framing the work to look creates the effect of looking through a window. The masking tape's provisional quality mediates this experience, but only temporarily as the tape's adhesive is engineered to hold for a short amount of time. The tape will fall off at some point. The work can only be seen through the lens of this mortality. The ambiguous landscape is only 
attainable when the veil of mortality is lifted. This experience becomes disorienting, mystical and contemplative, resulting in a body of work that illustrates the desire for immortality as we stand at the brink of the undefined.

\section{Part 2: The Binary}

The desire to establish a legacy is an attempt to solidify the central location between binary oppositions. Legacy exists after life and before death. It is the purgatory that recycles names. To understand how legacy functions between binary oppositions we must first establish a simple understanding of what binary oppositions are.

Binary oppositions are constructed of two parts. These parts are opposite in meaning. A simple example is darkness/light. Without an understanding of the meaning of darkness, we cannot understand the meaning of light. As binaries, you also cannot have both at the same time. To quote the Tao Te Ching, "These two enter the world alike, but their names are different. ${ }^{, 4}$ The difference between darkness/light is derived from the same experience. The understanding of light to be light only creates the concept of darkness.

For the purposes of this thesis binary oppositions are presented as equals and cannot be easily reduced to either side. Not being easily reduced to either side allows the opportunity to sustain myself in an in between state,

4. Tzu, Lao. Tao Te Ching: An All-New Translation. Translated by William Scott Wilson. Kodanasha International. Tokyo. 2010. Page 49 
struggling between handedness/unhandedness, presence/absence and materiality/illusion.

\section{Part 3: Immortality Narratives}

In the opening lines of the preface of Stephen Cave's Immortality, he states, "This is a book about life, death and civilization". ${ }^{5}$ Cave goes on in this preface to state the intentions of the book, which are simple:

To show how we, like all living things, are driven to pursue life without end; but also how we, alone of living things, have in the process created spectacular civilizations, with stunning artworks, rich religious traditions and the intellectual achievements of science. ${ }^{6}$

It is promised that these intentions will be realized by outlining four paths that civilization has followed on the quest for immortality. They are as follows:

Elixirs, Resurrection, The Soul and legacy. " "These narratives are responses to fundamental constants in the human condition". ${ }^{8}$ They are common throughout many cultures and some have been elaborated on to great extent. It is through these immortality narratives that artists have made their greatest creations and these works are left behind so others can continue enjoying them.

For the purpose of this thesis I would like to focus solely on legacy. Although this body of work does put forth a mystical experience it does not provide a narrative for what happens beyond immortality. It does however

5. Cave, Stephen. Immortality. Crown Publishers. New York, New York. 2012. Page ix

6. Cave, Stephen. Immortality. Crown Publishers. New York, New York. 2012. Page ix

7. Cave, Stephen. Immortality. Crown Publishers. New York, New York. 2012. Page ix

8. Cave, Stephen. Immortality. Crown Publishers. New York, New York. 2012. Page 3 
deal with the physical trace I leave behind as an artist. This can be seen as a legacy and does not require the survival of me as a person. Cave presents a contemporary view on cultural legacy:

...The modern cults of film stardom and TV celebrity, mass-market magazines and instant communications have transformed it from an elite occupation to the career of choice of thousands. ${ }^{9}$

Our obsession with immortality has led us to turn our quest into occupation. Each day focus is placed on working to be the next big thing. It is imperative in the art world that an artist be embraced during their lifetime to procure their spot in the pantheon/museum. The goal of museums is to maintain the artist's legacy through devices of preservation. With the other immortality narratives falling short of reaching actual immortality, cultural legacy presents itself as the last option. The question that I have struggled with during the course of this project is where is my hand in work that has become my path to immortality?

The legacy of an artist allows them to inhabit a kind of purgatory, a waiting room where they are physically dead, but the preservation by the museum continues to keep them around. David Eagleman, a neuroscientist at the Baylor College of Medicine presents a similar idea when he speaks about death. He sums up how I understand the artist's life eloquently:

There are three deaths. The first is when the body ceases to function. The second is when the body is consigned to the grave. The third is that moment, sometime in the future, when your name is spoken for the last time. ${ }^{10}$

9. Cave, Stephen. Immortality. Crown Publishers. New York, New York. 2012. Page 205

10. Eagleman, David. Sum: Forty tales for the Afterlives. Pantheon Books.

New York, New York. 2009. Page 31 
An artist that has been embraced by the museum never gets to leave this purgatory. Never reaching his/her third death, he/she is resigned here for eternity. This purgatory is what many call posterity. As an artist the desire for posterity is impossible for me to escape. There are two chapters in this thesis that are dedicated to Trompe L'oeil painting and Minimal Art two modes of making that have achieved legacy despite the removal of the hand. All of these establish a legacy and if embraced, grant access to the to the museum. The binary opposition of marked and unmarked suggests difference, however, when it comes to establishing a legacy they achieve the same goal.

Functioning between life and death, posterity cannot grant either. Posterity exists after life and before death. I am interested in the centrality of this space. It is here that I must ask which legacy do I choose to carry on? Where do my passions lie? And, how in the world do I begin to do so? I enjoy the flourishes of trickery employed in trompe l'oeil painting and the antiillusionary quality of Minimal Art equally. What is lost in Minimal Art is the use of materiality to create illusion. When Minimal art had achieved a point where a painting could be anti-illusionary it became binary to trompe l'oeil painting. The goal in my work is to render the work undefined by each individual term, however defined by both equally. In doing so, Materiality falls into an illusion and trompe l'oeil effects do not deny the tangibility of the work. The importance here is that I have created an experience where the viewer peers through a fake window and is confronted with reality. 
The larger paintings title Above Mount Fuji (Figure 1) and Atop Mount Fuji (Figure 2)are made using laser jet transfers of foggy landscapes that are then covered with even strips of masking tape, positioned horizontally, edgeto-edge, creating a veil over the laser jet transfer.

The imagery is tiled onto the hardboard panel using sixteen, ten-inch squares, constructed in a four by four grid. The grid is used here for its history as a device existing between illusion and flatness. Rosalind Krauss explains that the grid is the link between Modern Art and everything that has come before. ${ }^{11}$ Krauss' reasoning for this is that it was through the grid that illusion was slowly removed from painting, culminating in the material and antiillusionary works of Frank Stella. The grid is the link between presence/absent and materiality/illusion. In this work is used to both construct imagery and also map the surface of the painting.

The imagery used in this work is derived from landscapes attributed to immortality narratives such as Mt. Fuji, and locations that suggest being geographically central, however are not. An example of a location that suggests being central geographically is Centralia, Missouri. There is also a Centralia in Pennsylvania. These locations all linguistically suggest that they are central to something, however, they are not geographically central to anything.

There are two paintings that use imagery from Mt. Fuji. Both images

11. Krauss, Rosalind. The Originality of the Avant-Garde and other Modernist Myths. MIT Press. New York, New York. 1985. Page 10 
are taken from the peak. The large paintings are constructed to with the intent of creating an illusionary and material surface. In doing so the trick of $19^{\text {th }}$ century trompe l'oeil painting is switched and the viewer is confronted with reality. Small aspects, such as the edge of the hardboard panel where the masking tape is cut precisely at the edge become small flourishes, where materiality and illusion are indistinguishable. As this center, an established the view from the immortal peak is rendered is indistinguishable.

A similar situation occurs when imagery from three Centralia locations (Figures 3-5) are appropriated and used in the same process of paintings using imagery of Mt. Fuji. With these paintings the imagery does not fully transfer to the hardboard surface. With each step the imagery becomes more ambiguous and less defined by actual geography of the photograph. The term Centralia becomes removed from the imagery and becomes descriptive of the work, not the actual geographic location. At the center of both the three Centralia paintings and the two Mt. Fuji painting is the idea that something is removed in order to achieve something else. At the center of the Mt. Fuji paintings an established immortal location is rendered indistinguishable. In the Centralia paintings the geographical location is removed in order to create an in between space. Both paintings remain central to mortality and immortality.

\section{Part 4: Presence/Absence}

Presence and Absence is a binary opposition. To make an analogy that clarifies my understanding of presence/absence and how it operates in my 
work I would like reference a quote from Lucius Annaeus Seneca: "Death is all that was before us. What does it matter, after all, whether you cease to be or never begin? When the result of either is that you do not exist." ${ }^{\text {, }}$ We have the ability to affirm our own presence by knowing objectively that we are still alive. We can feel our heartbeat, count our breaths and put our hand in our field of view, moving it on command. The natural fear of death comes from the absence of this objective proof.

As humans we are unable to imagine our [own] inevitable state of absence. [Our] powerful intellects come inexorably to the conclusion that we, like all other living things around us, must one-day die. Yet on the other, the one thing that these minds cannot imagine is that very state of nonexistence; it is literally inconceivable. ${ }^{13}$

As humans we can define our presence at any point, but to think about our absence or the state of being dead is unimaginable. To even think about our state of nonexistence establishes our presence, therefore, making imagining death impossible.

To imagine death is a sublime experience. It is an experience where the fear of death and the beauty of life are overwhelming. George Kateb, a William Nelson Cromwell Professor of Politics, Emeritus, at Princeton University explains this eloquently in the March 2011 interview George Kateb: Epicurean thoughts on death. In this interview he says, "You came from nothing and you go to nothing. Your existence is a moment of being."14

12. Lucius Annaeus Seneca and Robin Campbell. Letters from a stoic. Penguin Books.London, England. 1969. Page 105

13. Cave, Stephen. Immortality. Crown Publishers. New York, New York. 2012. Page 16 14. Kateb, George. Interviewed by Tyler Krupp and Rachel Stuart. Epicurean Thoughts on death. thinkingaloud.com. July 18, 2012. accessed March 17, 2014. http://www.youtube.com/watch?v=SjwEZG5OtoA. 
This statement presents a rational way of dealing with our inevitable death that recalls the poem by Halpern. Once our existence is complete we will return to the beginning or nothingness. All that is left is the physical trace of being.

Exploring the relationship between presence/absence in art is not a new idea. Rachel Whiteread, a contemporary British sculptor, has been working with presence/absence by casting the negative spaces of material objects. An example of this is Ghost, 1989 (Figure 6). Ghost is a cast of the interior parlor in a middle class north London home. These homes were slated to be demolished. The cast was constructed by making a structure similar to a scaffold in the interior of the home. Plaster was then poured in to fill the interior. Once the plaster cures completely, the home was carefully dismantled around the cast. This left a solid cast of the interior space. On the surface of this cast was the imprint of the interior of the home. The empty space was made solid. The wainscoting, crown molding and embellishments were now in reverse. Over the fireplace was the residue of soot that had not been cleaned from the wall standing as a trace of past fires that were kept. Traces such as the soot over the fireplace remind us of what happened in this parlor and the comforts of home.

House (Figure 7) was made early is a series of works that Whiteread made in dilapidated areas around London. In 1993-94 Whiteread filled a home in east London with concrete. The cast was made in three layers. Each layer 
has a metal structure placed inside and then was filled with concrete. In the final cast the floors of each layer of the home are trapped in the dried concrete, but exposed where they attached to the walls of the home. When the layers were filled with concrete and had dried the exterior of the home was carefully removed. The destruction of this home caused controversy. The debate encompassed the state of housing and right-wing conservative racism, but more importantly focused on a now lost life. "House Materialized the fragile symbolic barrier between absence and presence... between things that should be hidden and things that should be shown". ${ }^{15}$ It does so by "silencing... the past life of the house, where the traces of that former life were "rendered dead but preserved." ${ }^{, 16}$ In other words it renders our nostalgic tendency to return home impossible. As now, the interior of the home we once inhabited has become solid. The space has been destroyed and the cast stands as a reminder of the unattainable past.

Uros Cvoro's writing on Rachel Whiteread's House is crucial to my work. Cvoro attempts to take Whiteread's investigation of presence/absence and extrapolate meaning from it. The idea that the past can be silenced and something dead can be preserved is impactful. Whiteread's House has become a representation of three deaths. The first death is when structure became uninhabited. The second is the removal of the structure and taking the

15. Cvoro, Uros. "The Present Body, The Absent Body, and the Formless". Art Journal. Vol. 61, No. 4 (Winter, 2002), pp. 54-63. accessed March 3, 2012. http://www.jstor.org/stable/778151. Page 62

16. Cvoro, Uros. "The Present Body, The Absent Body, and the Formless". Art Journal. Vol. 61, No. 4 (Winter, 2002), pp. 54-63. accessed March 3, 2012. http://www.jstor.org/stable/778151. Page 62 
remnants to the landfill. The third, we are still waiting for, the moment when the work is spoken about for the last time.

The choice of temporal materials in my work is an attempt to straddle this the idea of presence and absence, challenging the viewer with eternal imagery and mortal materials. The work is intended to be impermanent. It is made with masking tape and other non-archival materials. The wait for the slow destruction of my work and the struggle to find my hand becomes symbolic of the fear of being forgotten. Once we are granted the third and final death, we are no longer immortal. The illusion of immortality has been exposed as a trick. We have passed completely through the threshold, exited purgatory and are finally forgotten.

\section{Part 5: Trompe l'oeil}

I will this chapter by introducing trompe l'oeil in painting and explaining its history and significance. Next I will locate aspects of this genre in my own work. Trompe l'oeil painting is a technique used to trick the viewer to believe that something non-existent is real. It presents an illusion of the material world to the viewer. For the purpose of this thesis Trompe l'oeil techniques are used to present the illusion of immortality that is obtained through establishing cultural legacy.

Earl A. Powell, the Director of the National Gallery of Art states:

As a rule, we do not like to be deceived. Even so, at least one notable exception exists: since antiquity, art lovers have taken delight in being tricked into mistaking, at least momentarily, painted illusions for the 
real thing. ${ }^{17}$

Often times these works are so meticulously painted that the objects within the frame seems tangible. It happens that this trick was the basis of a painting contest between Zeuxis and Parrhasios. To paraphrase, the contest was between Zeuxis and his Contemporary Parrhasios. Zeuxis unveiled a painting of grapes in front of Parrhasios. Birds then flew down and began pecking the surface of the painting when the painting was uncovered because it looked so real. When it was time for Parrhasios to reveal his painting, he let Zeuxis do the honor of uncovering his painting. As Zeuxis reached out to grab the cloth covering the painting, he was confronted with its flatness. Zexius was able to trick the birds into believing the grapes were real, but Parrhasios was able to trick Zeuxis that his painting was in fact draped in cloth. ${ }^{18}$

In 1964 Jacques Lacan uses this same story in his essay, What is a picture? from Book XI of The Seminars of Jacques Lacan. To paraphrase Lacan, if the dabs of color applied to the surface of the painting by Zeuxis made the birds think the picture contained actual edible grapes does not imply that the reproduction was good. Lacan goes on to reference Caravaggio's Bacchus as being a way of depicting grapes that would have not fooled the birds. ${ }^{19}$ This reference is subjective and obscures the point that "trompe

17. Powell, Earl A. Forward. Five Centuries of Trompe l'oeil painting: Deceptions

Illusions. Sybile Ebert-schifferer...[et al.\}. National gallery of Art. Washington, D. C. 2002. Page 9

18. Milman, Miriam. The Illusions of Reality: Trompe-L'oeil Painting. Skira, Rizzoli Geneva, Switzerland. 1982. Page 6

19. Lacan, Jacques. The Four Fundamental Concepts of Psychoanalysis. The Seminar of Jacques Lacan book XI. Edited by Jacques-Alain Miller. Translated by Alan Sheridan W.W. Norton and Company. London. 1998. Page 111 
l'oeil... pretends to be something other than what it is" ${ }^{20}$ The point here is that the trompe l'oeil painting done by Zeuxis was closer to what real grapes look like. Animals are enticed by what is superficial, meaning they are only concerned with what is on the surface. Humans on the other hand are enticed by what is hidden. Lacan states "Parrhasios makes it clear that if one wishes to deceive a man, what one presents to him is the painting of a veil, that is to say, something that incites him to ask what is behind it." ${ }^{, 1}$ The attraction of a trompe l'oeil painting is the trick. We know there is nothing behind the veil as it is just a trick yet we continue to be enticed to lift it and see what is behind it. Trompe l'oeil paintings are best when the illusion is of a shallow twodimensional space. Painters such as John Haberle, William Harnett and John Frederick Peto used this technique in their work by draping cloth over a table or placing objects on a shelf that is attached to a wall. They then paint from these still life set-ups. The importance of these artists rests in their renderings of everyday objects in this shallow two-dimensional space. Jumbled books, playing cards, pipes and revolvers were often the subjects of their works. Through the use of these everyday objects they were able to capture the temporal moments of everyday life such as the passage of time or the gambles one would take in their life. The intent off these artist's works is to have the

20. Lacan, Jacques. The Four Fundamental Concepts of Psychoanalysis. The Seminar of Jacques Lacan book XI. Edited by Jacques-Alain Miller. Translated by Alan Sheridan. W.W. Norton and Company. London. 1998. Page 112 
viewer reach a mystical state. A mystical state in which they can contemplate life as it exists beyond the veil of materiality.

In 1890 William Harnett finished the Faithful Colt (Figure 8). This painting was done with oil paint on canvas and resides in Wadsworth Atheneum in Hartford, Connecticut. This painting depicts a Civil War era revolver hanging on a weathered door made of bead-board. The bead-board is painted in a blue-gray paint and coated with a varnish that is cracking and chipping away. There are large cracks and holes in this door. In the upper left hand section of the painting we see two large splits in the bead-board door, allowing us to peer into an ambiguous dark space resting just beyond the door. On the center, vertical axis of the painting the handle of the revolver faces upwards, while the barrel angles down towards the bottom left of the painting. The frame of the revolver, which is the part of the gun that protects the trigger, hangs on a nail. Below the revolver and to the right is a yellowed and chipped newspaper clipping painted in a way that tricks us into believing it is real. There are small shadows under the newspaper that look as the light moving across the surface has cast them. The shallow depth removes any distortions and the illusion becomes incredibly deceiving.

This work by Harnett is a trompe l'oeil painting. It looks as though the revolver hanging on the nail is tangible. Objects are painted life-size. The bead-board door provides the shallow two-dimensional space that makes trompe l'oeil paintings successful. In the words of Cécile Whiting from his essay Trompe l'oeil and the Counterfeit Civil War, "Harnett situated the 
revolver against a seemingly flat surface; in this manner he avoided the strong optical distortion that would have immediately revealed the deception". 22 This, along with the high level of detail seen in the revolver creates the illusion of the revolver and nail head protruding from the surface. These objects that are now protruding from the surface allowing the effect of light moving across the surface to become compounded. This effect makes the revolver seem tangible.

Harnett's painting was completed twenty-five years after the close of the American Civil War. Trompe L'oeil paintings of the late $19^{\text {th }}$ century “...evoked the Civil War... memorializing the receding conflict. They did so... with rhetorical knottiness and lack of resolution”. ${ }^{23}$ In Whiting's essay he begins with a description of Harnett's Faithful Colt, a description that came with it in an auction catalogue from 1893. The text described the painting as being a Civil War era Relic, specifically from Gettysburg. This information was semipublic and almost impossible to validate. What the revolver was meant to appear as was " as a survivor[s] from an earlier era." ${ }^{, 24}$ To evoke the Civil War, Harnett used a revolver from that period. The scratches, patina and cracks in the handle are the index of the revolvers past. This index authenticates the revolver as a relic of a past time and brings it distinctly into

22. Whiting, Cécile. "Trompe l'oeil painting and the Counterfeit Civil War". The Art Bulletin. Vol. 79, No. 2 (Jun., 1997), pp. 251-268. accessed March 17, 2014. http://jstor.org/stable/3046245. Page 252

23. Whiting, Cécile. "Trompe l'oeil painting and the Counterfeit Civil War". The Art Bulletin. Vol. 79, No. 2 (Jun., 1997), pp. 251-268. accessed March 17, 2014. http://jstor.org/stable/3046245. Page 251

24. Whiting, Cécile. "Trompe l'oeil painting and the Counterfeit Civil War". The Art Bulletin. Vol. 79, No. 2 (Jun., 1997), pp. 251-268. accessed March 17, 2014. http://jstor.org/stable/3046245. Page 252-253 
the present.

This quality of bringing the past to the present reminds me of the function of the museum. The constant recirculation and preservation of the works in the museum continuously recycle the legacy of the artists who made them, granting them immortality through posterity. Like the museum, Trompe L'oeil paintings are able to keep oppositions at a point of equilibrium. Harnett was able to establish both the presence and the absence of the American Civil War by using the revolver. The revolver stands as a trace of a past time, while the trompe l'oeil techniques of light being cast on surfaces; high detail and shallow two-dimensional space make the revolver seem tangible. It is here that Harnett has us contemplating the unattainability of the revolver and its temporal quality. The revolver is a device that takes life; the cracks and scratches on the handle make it look as though it has been used. Harnett leaves us with an unresolved space. Our senses have been deceived and we are left in a mystical state contemplating what is tangible and what is illusion.

As viewers we enjoy this. We want to pull the veil on everything illusionary. In many narratives of the afterlife we are able to extend beyond material world and inhabit a mystical space. The denial of the material object in trompe l'oeil painting was intended to create a contemplative state that allows for spiritual enlightenment. The message was to not focus on the material world, but on the afterlife. The afterlife, however, is also a trick.

The afterlife of an artist is cultural legacy. Legacy provides and alternate ending to an otherwise rational existence. This reverts back to 
Lacan's explanation of why trompe l'oeil is able to trick the human senses. In some way, shape or form they suggest the possibility of lifting the veil on our material existence, providing something other than an end of long dreamless sleep. My work shares the erasure of the hand with trompe l'oeil painting. The tape on the surface and the illusion of light moving across the surface present both pure illusion and anti-illusion to the viewer. This causes confusion, yet does not deny pure illusion or anti-illusion. Instead the work does not reduce easily to either side of the binary opposition. This provides a space, similar to the purgatory provided by cultural legacy, where the viewer remains simply in between.

SHIFT I and AMID I (Figures 9-10) were created by using paint overspray and were twenty inches wide by twenty inches high. The surface that the masking tape was attached to was made of Masonite hardboard and plaster, sanded to create a concave surface. Around the perimeter of these works was a three-inch boarder, painted with flat-black latex paint and applied with a smooth finish brush to limit the evidence of the brush strokes. On the outer perimeter was a white wooden frame made. This frame extended onequarter of an inch in width from the edge of the white boarder making the total size of the painting twenty-six inches by twenty-six inches and one and three-quarter inches deep.

Four devices are used as a frame in these oblique spray-painted paintings. The wood frame on the edge, the flat-black boarder and the edge around the spray-painted center square measuring twenty inches square, each 
function to create the appearance of a window. Between the flat-black border and the white frame there is a shadow line. This device provides a visual break between the black boarder and the white frame. It is recessed threesixteenths of an inch and is one-eighth of an inch wide.

In the center of the painting is the twenty inch by twenty inch, flatblack square with a piece of masking tape attached to its surface. The bottom of this panel is darker than that top. The dusting of spray paint applied over this surface was applied in a gradient from the top down. The top was closer to the nozzle of the spray paint can, and the flat white paint adheres more at the top and less at the bottom. The spray paint atomizes the further it moves from the nozzle of the paint can creating a speckled, less opaque finish at the bottom. The transparency of the areas where the paint had atomized before it reached the surface creates tonal shifts between the flat-black paint and the stark white of the spray paint. This light over dark technique is a technique used in painting to achieve these tonal shifts without having to mix the colors on the palette and then apply them to the surface.

The tonal shifts created by spraying white paint over the dark surface of the flat-black paint create the effect of light moving across the surface. The paint catches on bits and pieces of tape that protrude from the surface. This technique creates the trompe l'oeil effect that confuses our senses. As the paint catches on theses highpoints it makes it look as though theses protrusions are coming our further than they really are. The hardboard panel creates the shallow two-dimensional space that makes trompe l'oeil effects so 
effective. The shallow space provided by the hardboard panel stops atmospheric distortion that exposes the trick immediately. The tape falls into illusion, masking its materiality.

\section{Part 6: Minimal Art}

I will begin by narrating a short history on Minimal Art, taking into account my decision to rest on Minimal Art rather than Minimalism. I will then relate this history to the paintings that I have made fore the Longitudes and Latitudes exhibition.

Minimal art was a term first coined in 1965 by Richard Wollheim, an English art-philosopher. ${ }^{25}$ It stands as the binary pair to Trompe L'oeil painting. While Trompe l'oeil painting attempts to trick us, Minimal art resists illusion and does not masquerade as anything other than what they are. There is no illusion, no metaphor. Canvas is canvas, paint is just paint and wood is just wood. None of these materials leads us to believe they are something else. Minimal Art was focused on reducing painting to a point where illusion was completely absent. Although Minimal art is in opposition to Trompe L'oeil painting it still establishes as cultural legacy in the same way. The work of art is made, embraced by the museum and recycles the name of the artist.

Minimal Art is different from Minimalism. Minimalism "is used to describe corresponding tendencies that have taken place in dance, music. Literature painting and sculpture since the early fifties, the description of 
Minimal Art is confined to the visual arts. ${ }^{26}$ Although as Minimal art progresses it transcends painting and extends primarily into sculpture and installation it has its root in painting. Minimal art challenges the "supremacy of painting within modern art" according to Daniel Marzona. It reduced painting from being a window, or an illusion, to being completely material.

To quote Frank Stella, "What you see is what you see" in Minimal Art. "The painting was accorded the status of an object.." ${ }^{27}$ To reduce a painting from being completely illusionary to being anti-illusionary was not instantaneous. The progression can be traced through the twentieth century. Rosalind Krauss exposes an important transition during this period in her essay Grids:

By "discovering" the grid, cubism de Stijl, Mondrian, Malevich.... Landed in a place that was out of reach of everything that went before. Which is to say, they landed in the present, and everything else was declared to be the past. ${ }^{28}$

The use of the grid was the first separation from a history of painting that was rooted in illusion. The grid was a device used to map the surface of a painting. This separation begins the flattening of pictorial space and begins to establish a binary opposition to $19^{\text {th }}$ century trompe l'oeil painting. The flattening of pictorial space culminates in "painting [taking] a breathtaking turn after the Second World War"29. In 1947 Jackson Pollock created his large, abstract, drip paintings and the avant-garde was moving towards large-scale

26. Marzona, Daniel. Minimal Art. Taschen. Köln, Germany. 2004. Page 6 27. Marzona, Daniel. Minimal Art. Taschen. Köln, Germany. 2004. Page 7 28. Rosalind, Krauss. The Originality of the Avant-Garde and other Modernist Myths. MIT Press. New York, New York. 1985. Page 10 29. Marzona, Daniel. Minimal Art. Taschen. Köln, Germany. 2004. Page 7 
abstraction. These large scale, abstract paintings, were not illusionary and were very flat. These characteristics would become the basis for Minimal art, allowing the reduction of painting to become solely material and antiillusionistic.

Frank Stella's Black Paintings favored materiality over illusion (Figure 11). Stella's Black Paintings were made using enamel paint used to paint houses. He used a brush to create equal stripes that were solid in the middle and rough on the edges. Between these stripes the pencil lines marking where Stella had laid out his composition can be seen on the canvas between the painted stripes.

"By stretching his canvases on supports a few centimeters broader and dispensing the frame, Stella seemed in addition to emphasize the sculptural aspect of his pictures." ${ }^{, 30}$ Stella's emphasizing the sculptural aspects of his pictures creates a painting that is material and anti-illusionary.

Stella's anti-illusionary, completely material paintings stand in opposition to Trompe l'oeil painting. Minimal painting, like the work of Frank Stella, is reliant on the painting competition between Zexius and Parrhasios as much as trompe l'oeil painting. Both Minimal Art and trompe l'oeil painting are interdependent and complimentary to one another. Minimal art can be easily reduced to anti-illusion, while in a trompe l'oeil painting the viewer is confronted with illusion.

In my work I present the viewer with materiality equally as much as I do with Illusion. The frame, the false matting and the image are all on the 
same plane. This presents a completely flat surface to the viewer, and denies any suggestion of depth. The wooden frame is left unsealed. It is just wood. the paint used to create the false matting has a flat, even finish, and masking tape is simply masking tape. These anti-illusionary characteristics of Minimal Art stand in opposition to the illusionary quality provided by trompe l'oeil techniques.

There is confusion created in my work between the material choice and its function within this body of work. Although the wooden frame, the false matt and masking tape remain simply materials, they also help to enhance the illusionary qualities in the work. The wooden frame and the false matt are just wood and paint respectively, however, they function to enhance the effect of looking into a window. The masking tape functions in a similar way. It presents itself to the viewer as masking tape, but the viewer can peer through it and see what is behind it. Masking tape is a physical mask but not a visual mask.

This material quality is most evident in the four devices that are used as a frame in these oblique spray-painted paintings and the large masking tape paintings The wood frame on the edge of the large paintings remains simply unfinished wood and the flat-black boarder and the edge of the smaller paintings is meticulously painted to be as smooth as possible. In both paintings there is a shadow line between the false matt and the frame

\section{Part 7: Materiality/Illusion}


The chapters on Minimal art and Trompe l'oeil painting present an important binary opposition: Materiality/Illusion. Minimal art was focused on being anti-illusionary and not allowing materials to transform into illusions. Minimal art remains completely material. Paint is paint and wood is wood. Trompe l'oeil painting allows paint to masquerade as something other than paint. Trompe l'oeil paintings are illusions. This is important to the materiality/illusion binary. When paint masquerades at something other than what it is, it loses its material qualities, reducing the binary to becoming solely illusionary. It is no longer just paint when it becomes something else.

In my work I try to remain central to this opposition. I employ materials for there material qualities equally as much as I do for their ability to create the effect of peering through a window. In doing so I am able to remain central to the materiality/illusion binary. Paint is just paint, but it also functions as a false matt, creating the effect of looking into a window. The same can be said for the directional spray painted pieces where the spray paint is simply spray paint, but it creates the illusion of light moving across the surface. Masking tape being a physical mask, but not a visual mask functions this way as well. It is satin, cream in color and stuck to the surface like it would be if I were going to paint around window trim. Its transparency, allows what is beneath it to be seen. This material quality evokes the sense that we are peering through a threshold to another space. The tape remains completely material, never transforming, only enhancing our understanding of the illusion the space beyond it. 
I am interested in the relationship between removing materiality from a surface and creating an illusion. It presented the possibility that making decisions based purely on materiality and not relying solely on trompe l'oeil painting techniques could create illusions. This way of working, and the mock-ups/sketches done to explore this idea, seemed to establish a central location between Minimal Art and Trompe l'oeil painting. In this space between the opposing pair I was able to begin to satisfy my desire for illusion when working in a minimal painting format. The resulting sketches were both material and illusionary and contained small flourishes of illusion created purely through careful construction and manipulation of materials.

The dusting of paint overspray became a way of working that allowed the work to exist between materiality/illusion. The work was both material and illusionary. The tape on the surface was present as a material and became absence as it fell into the illusion created by the paint overspray evoking the sense that light was moving across the surface. This allowed the work to not be easily reduced to either side of the binary pair, it retained the quality of being both material and illusionary and reversed the trick inherent in $19^{\text {th }}$ century trompe l'oeil painting, confronting the viewer with reality not illusion.

\section{Part 8: The Index}

The index is a physical trace of a lost event. We hold onto these physical traces in an effort to access the past. With my particular skillset the 
physical trace is always removed completely in order to achieve smooth surfaces and leave no evidence of the hand. The lack of the hand in my particular skill set has removed any chance of establishing of making a mark, being remembered or establishing a legacy. I attempt to leave the trace of my hand in scraps of masking tape and slightly wavering lines stand that out against perfectly painted boarders and obsessive application of long strips of tape. These traces allow the viewer to be transported to the exact moment when something was made. These traces are inseparable from the even that created them. ${ }^{31}$

The ability to return to the past is accessible through the index. In the boxes in the attic and in the frames on our mantles and our bookshelves we have compiled various indexes. Locks of our children's hair are stowed away in envelopes, signifying the child's first haircut. Proudly presented in frames are graduation pictures and diplomas. As Roland Barthes explains "the photograph mechanically repeats what could never be repeated existentially". ${ }^{32}$ What Barthes means by this statement is that the photograph cannot be separated from the event in which it was taken. Like the photograph, the marks left in my work become the event that created them; each time they are reproduced it indicates something "that-has-been". ${ }^{33}$

31. Barthes, Roland. Camera Lucida: Reflections on Photography. Translated by Richard Howard. Hill and Wang. New York, New York. 1980. Page 2

32. Barthes, Roland. Camera Lucida: Reflections on Photography. Translated by Richard Howard. Hill and Wang. New York, New York. 1980. Page 2

33. Barthes, Roland. Camera Lucida: Reflections on Photography. Translated by Richard Howard. Hill and Wang. New York, New York. 1980. Page 74 
The photograph, the footprint in Halpern's poem and my marks are unable to be separated from the event that made them. These indexical signifiers allow us the opportunity to maintain a sense of presence, as these events are lost. With each step the wavering border made by my hand becomes present and signifies my absence from a point in time. I have left, and something that is traceable remains. The viewer can see where I have placed the tape and paint, but the event is lost. It is in this moment that I become both present and absent.

The index is a device used to establish the presence/absence binary. Through the index we are able to physically trace our movement, affirming our existence and also use it to represent absence. In my work this index exists as a mistake. Leaving the trace of my hand in modes of making heavily reliant on the absence of the hand. This can be seen in the wrinkles of masking tape, the wavering of the flat black border around the perimeter of the shift and amid series. The evidence of this index causes confusion between materiality and illusion, exposing the trick and confronting the viewer with reality. This is supported by the precise application of masking tape over image transfers. The process of transferring the image is additive, meaning the image is added to the surface, however the paper that carries the image must be abraded away in order to reveal it. During this process the some of the image is removed leaving imperfections.

These imperfections become my mark, existing behind the layer of masking tape and making the misty, cloudy landscape more ambiguous. The 
index in this case allows for the manipulation of the ambiguous landscape because it is created through an understanding of materiality. We cannot separate the painting as a whole from the even of its creation. We are left to contemplate and define the ambiguous landscape through an understanding of materiality/illusion and presence/absence. Peering through the tape we are always trying to pull the veil on the illusion of what exists beyond it.

\section{Part 9: Longitudes and Latitudes}

This body of work begins and ends with a struggle to find my hand, my mark and my legacy in a skillset designed to render it absent. I find it refreshing that in many ways I have cycled back to the beginning of the project as I continue to struggle with how to leave a mark, be remembered and establish a legacy. This struggle continues to exist somewhere between presence and absence, evoking the Dao belief that the undefined is the beginning of the universe.

The use of non-archival materials and eternal imagery can be seen in the forty inch by forty inch paintings titled Above Mt. Fuji, Atop Mt. Fuji, Centralia, Mo. \#1, \#2 and Centralia, PA. These works challenge the viewer to peer through mortality as they try to define the landscape existing beyond. In series of smaller spray painting works title SHIFT and AMID, the flourishes of trompe l'oeil tricks are employed to confuse the viewer, forcing them to contemplate what is illusion and what is anti-illusion. 
The installation images are also included to show how the presentation of the work in the gallery space compounds the feeling of longing for legacy, remembrance and the expressive hand. The Centralia paintings are floated in the center of the gallery. Cleanly displayed, from a distance the hanging hardware is almost invincible. There are small moments where hand painted lines waver, or pieces of tape do not quite line up challenging the removal of the hand through fine craftsmanship. They are moments where my fear of being forgotten provokes me to challenge my skillset and attempt to make my mark and obtain posterity.

The exhibition as a whole remains central to the binary oppositions of presence/absence, materiality/illusion and handedness/unhandedness, urging the viewer to contemplate these binaries and their relationship to legacy. In a society that is constantly on a quest to stake their claim in purgatory, it seems impossible to exist outside of these binary oppositions. The illusion of immortality is sought through the material world. In this work you must peer through mortal materials to see what exists beyond them. The eternal is achieved through the physical traces we leave in the temporal space we currently inhabit. To leave no trace, no residue, is to always operate in the present. "Make definitions, and you are the measure of all creation." ${ }^{34}$ To have no desire to stake a claim in purgatory, we are about to peer deep into the transcendent.

34. Tzu, Lao. Tao Te Ching: An All-New Translation. Translated by William Scott Wilson. Kodanasha International. Tokyo. 2010. Page 49 


\section{Illustrations}

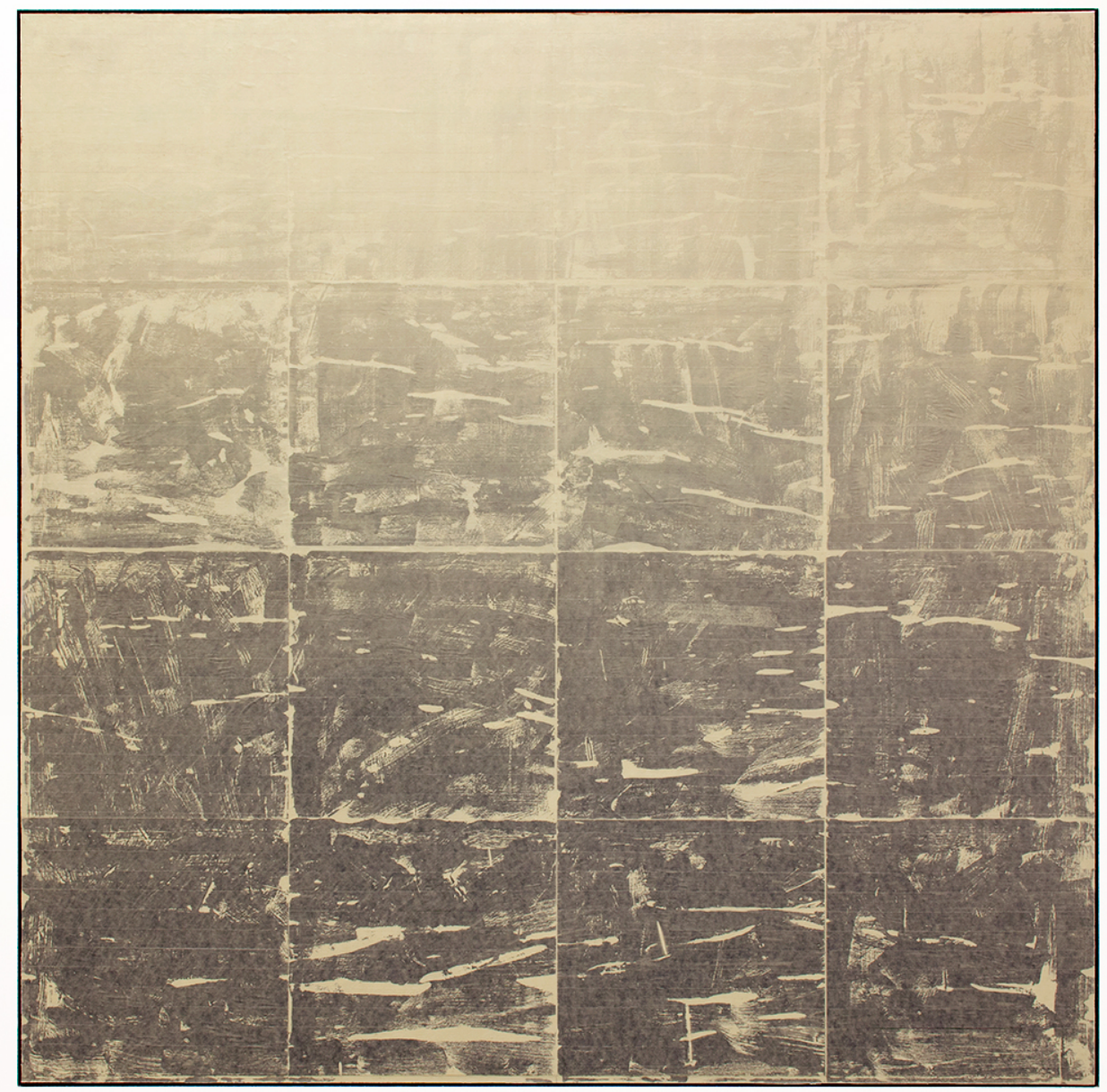

Figure 1

S. Charles Thmopson

Above Mt. Fuji

Laser Jet Transfer, Masking Tape 49.5 " x 49.5"

2014 


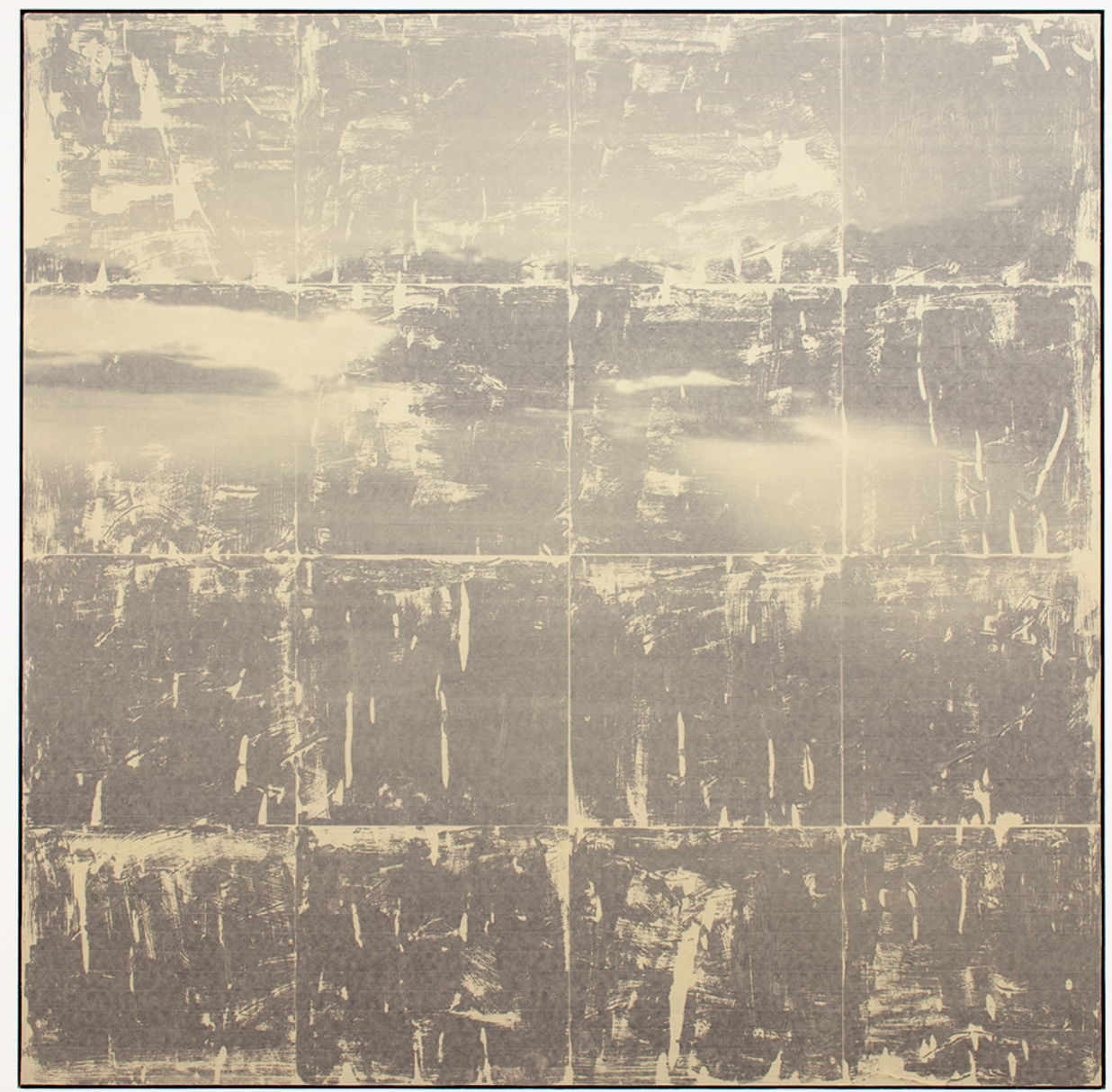

Figure 2

S. Charles Thompson

Atop Mt. Fuji

Laser Jet Transfer, Masking Tape

49.5 " x 49.5"

2014 


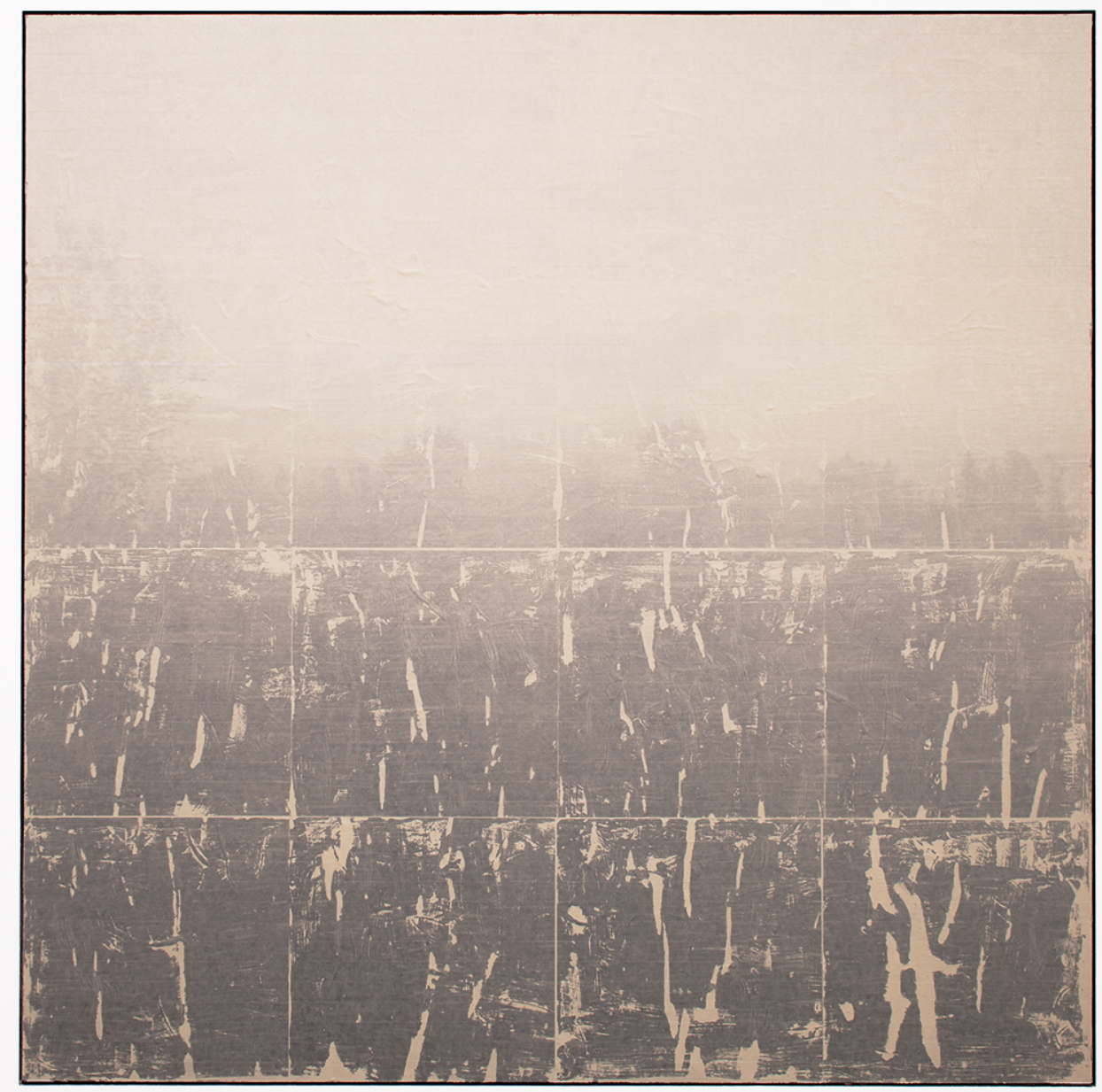

Figure 3

S. Charles Thompson

Centralia, Mo., \#1

Laser Jet Transfer, Masking Tape

49.5 " x 49.5"

2014 


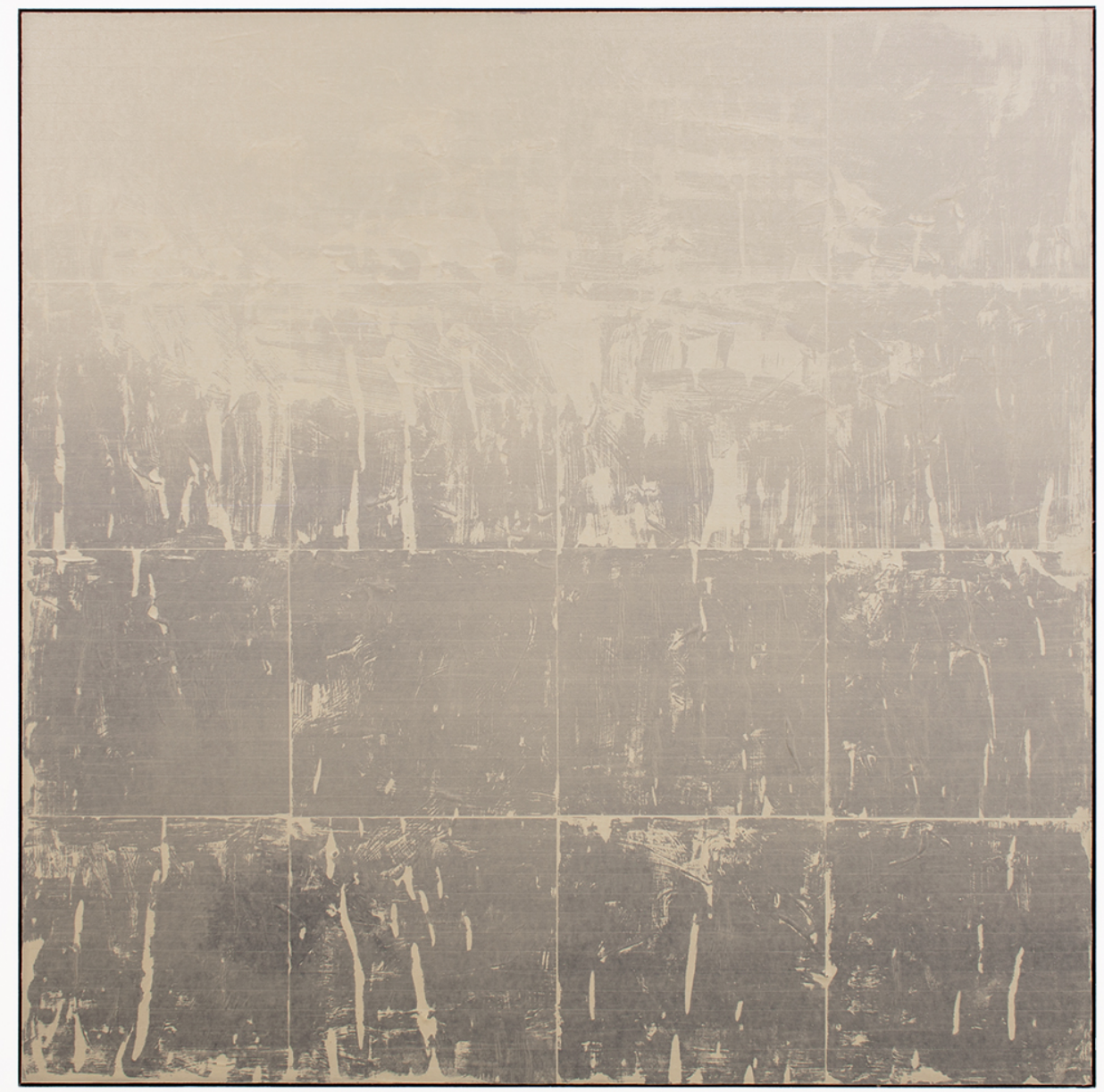

\section{Figure 4}

S. Charles Thompson

Centralia, Mo., \#2

Laser Jet Transfer, Masking Tape

49.5 " x 49.5 "

2014 


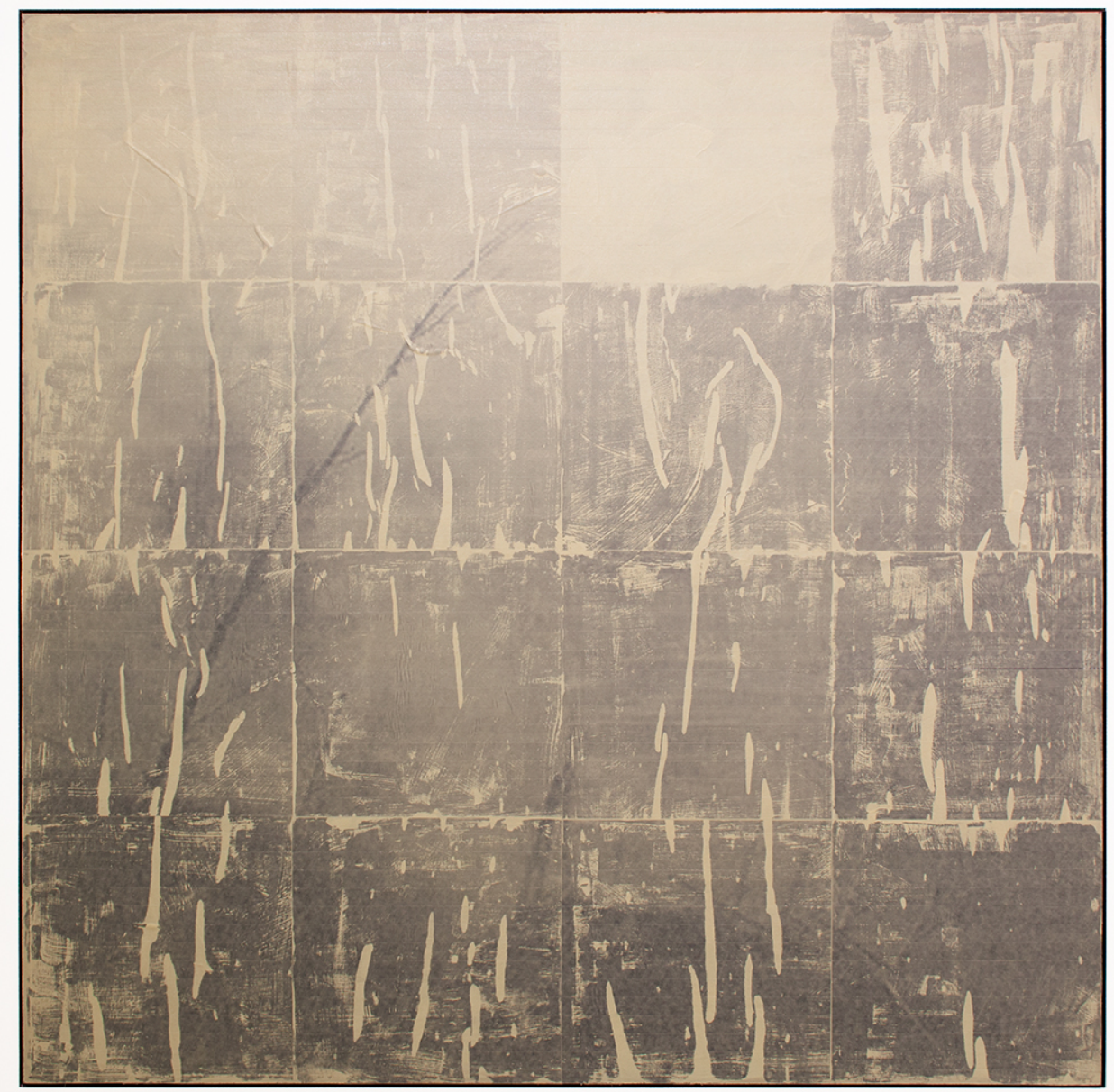

Figure 5

S. Charles Thompson

Centralia, $\mathrm{Pa}$

Laser Jet Transfer, Masking Tape

49.5 " x 49.5"

2014 


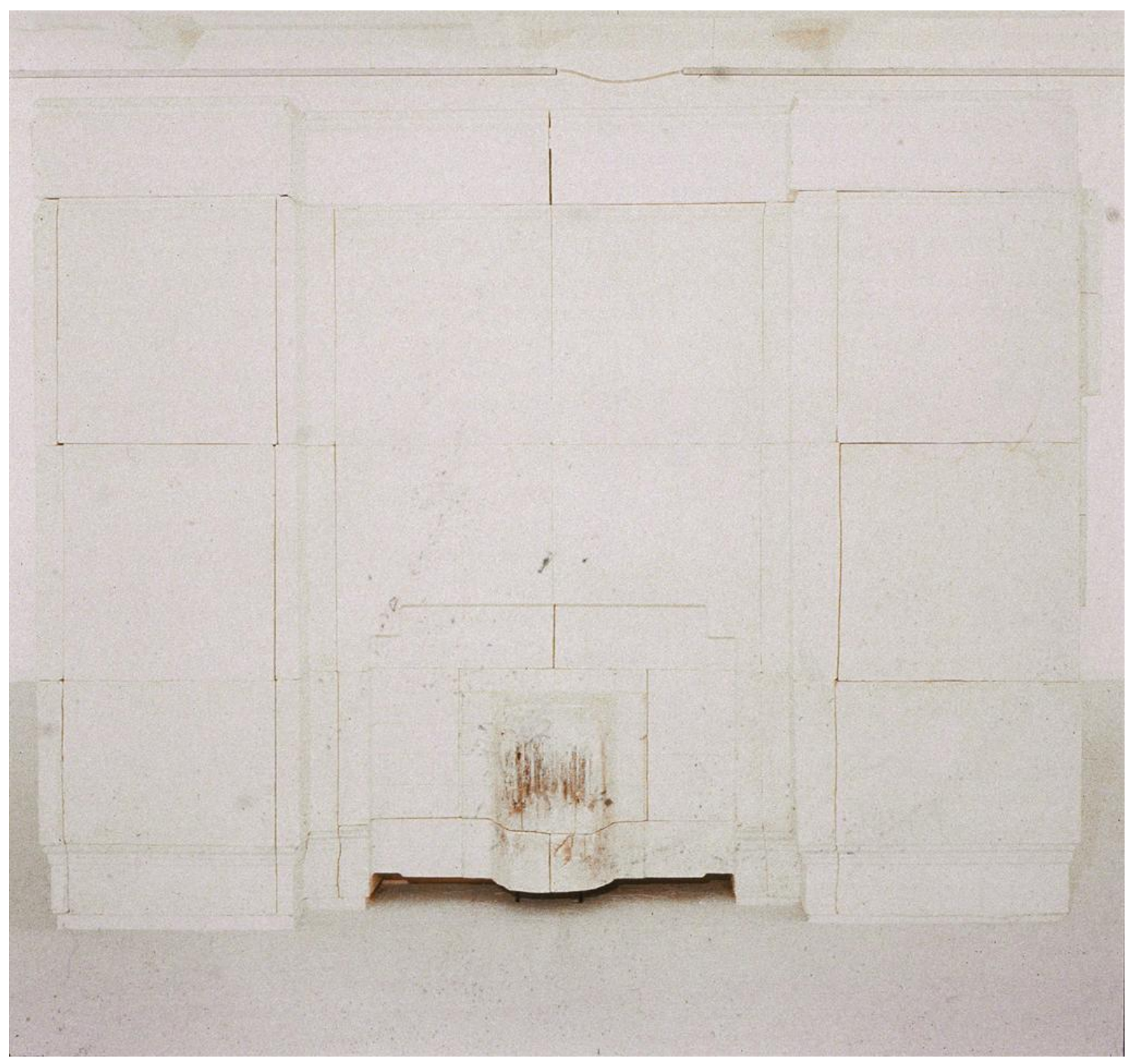

Figure 6

Rachel Whiteread

Ghost

Plaster on Steel Frame

8'10" x 11"8" x 10'5"

1990

ARTSTOR 


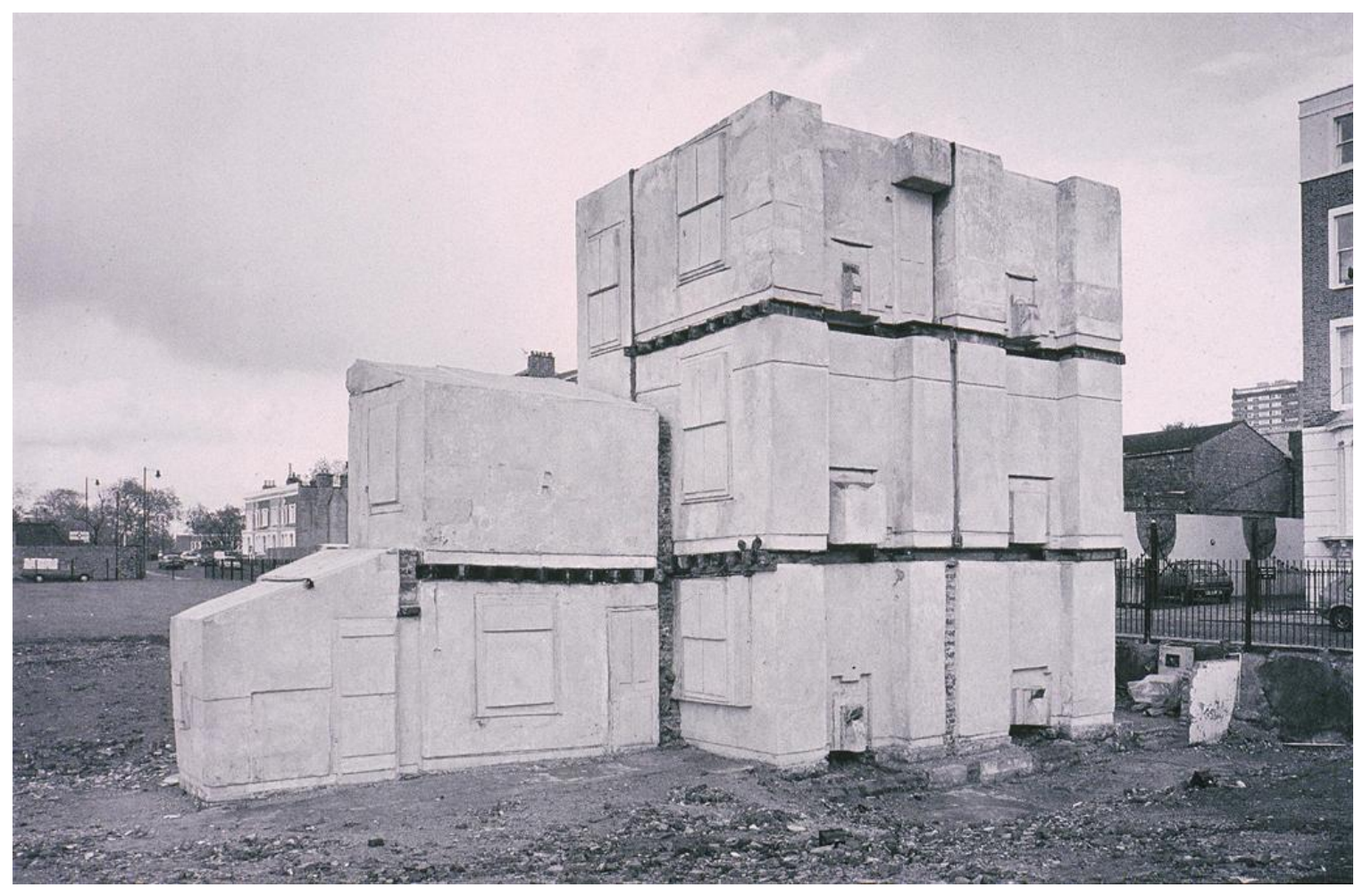

Figure 7

Rachel Whiteread

House

Concrete

1993-4

ARTSTOR 


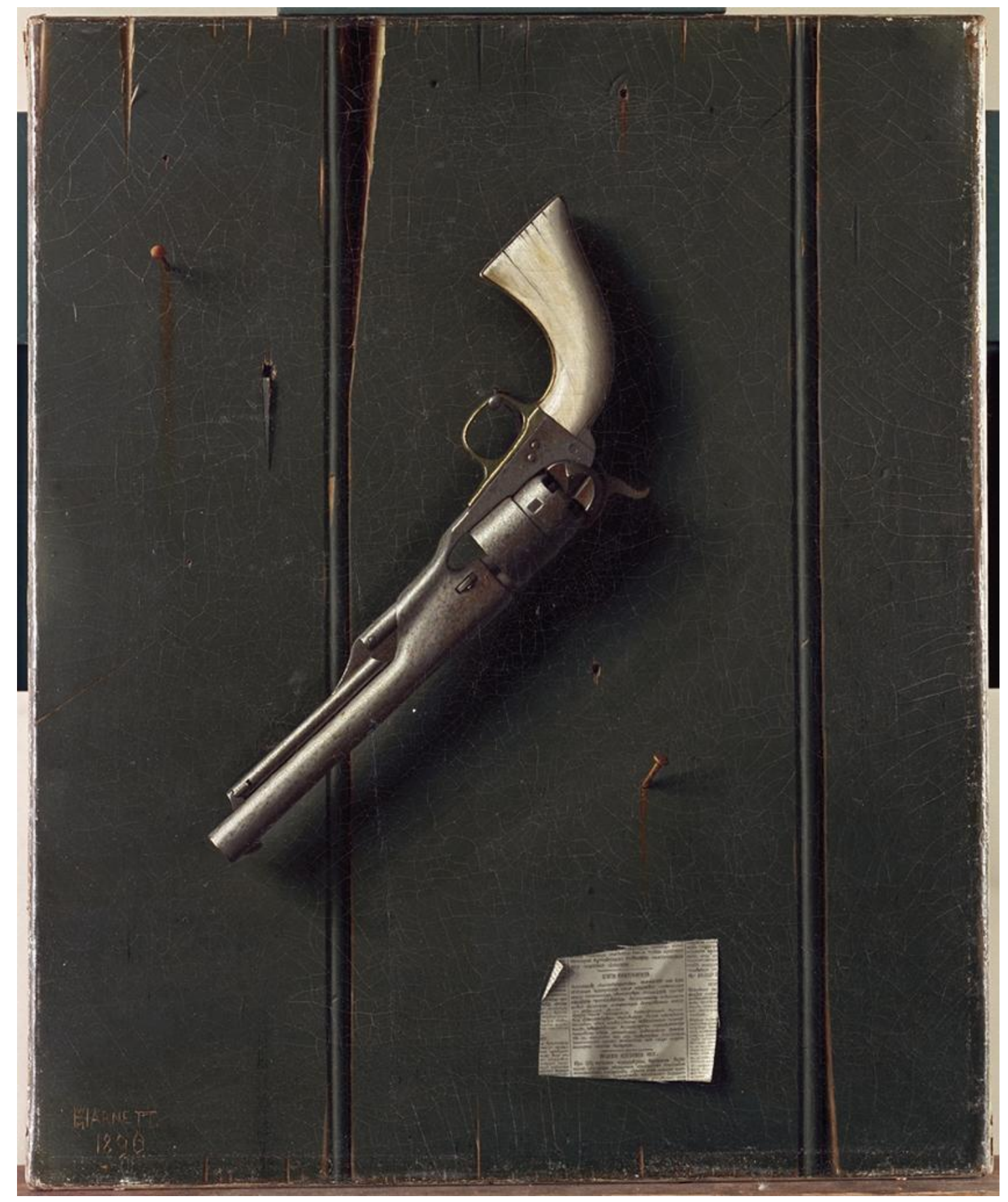

Figure 8

William Harnett

Faithful Colt

Oil on Canvas

22.5 " x 18.5"

1890

ARTSTOR 


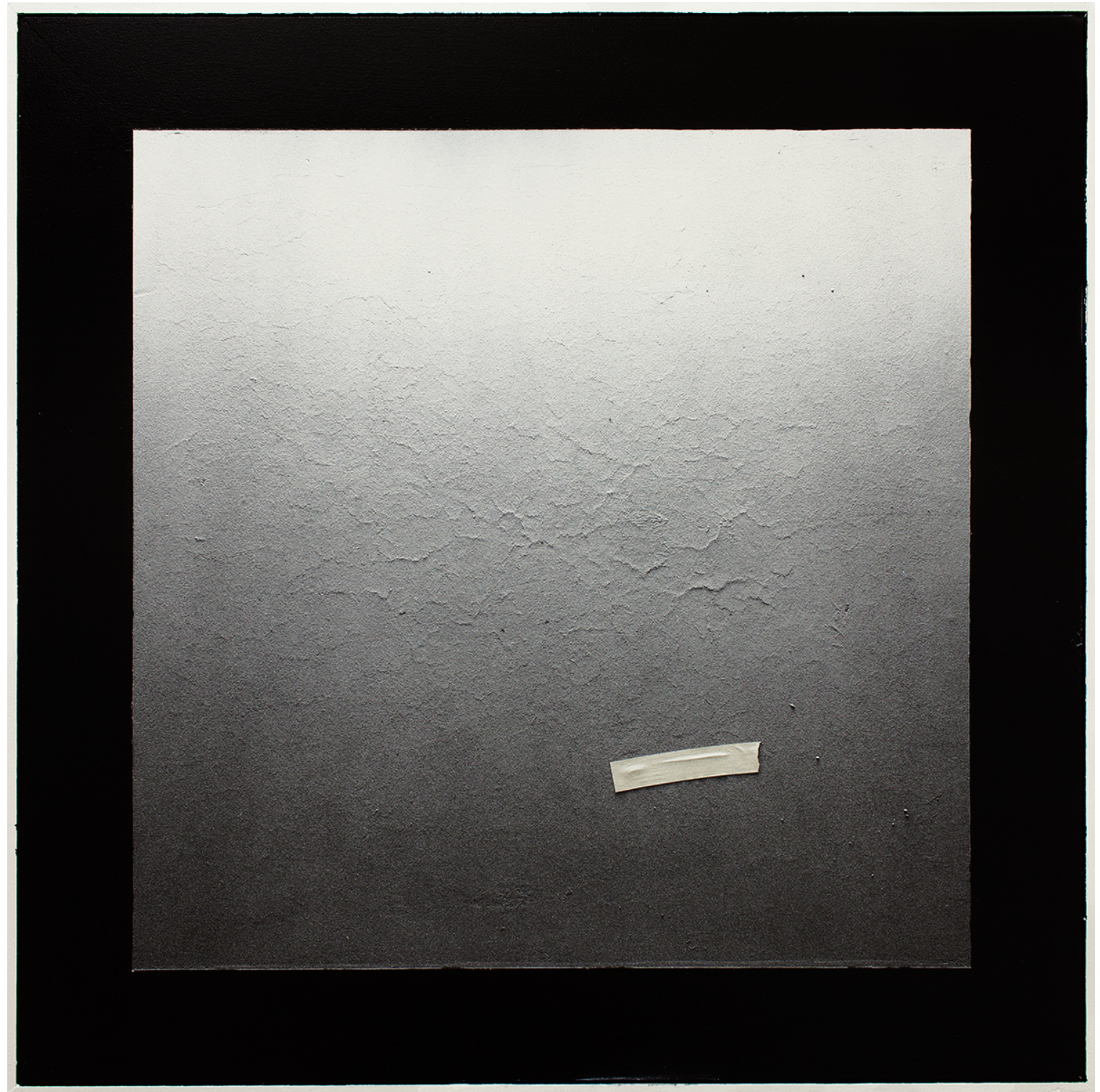

Figure 9

S. Charles Thompson

SHIFT I

Masking Tape, Spray Paint

26 " x 26"

2014 


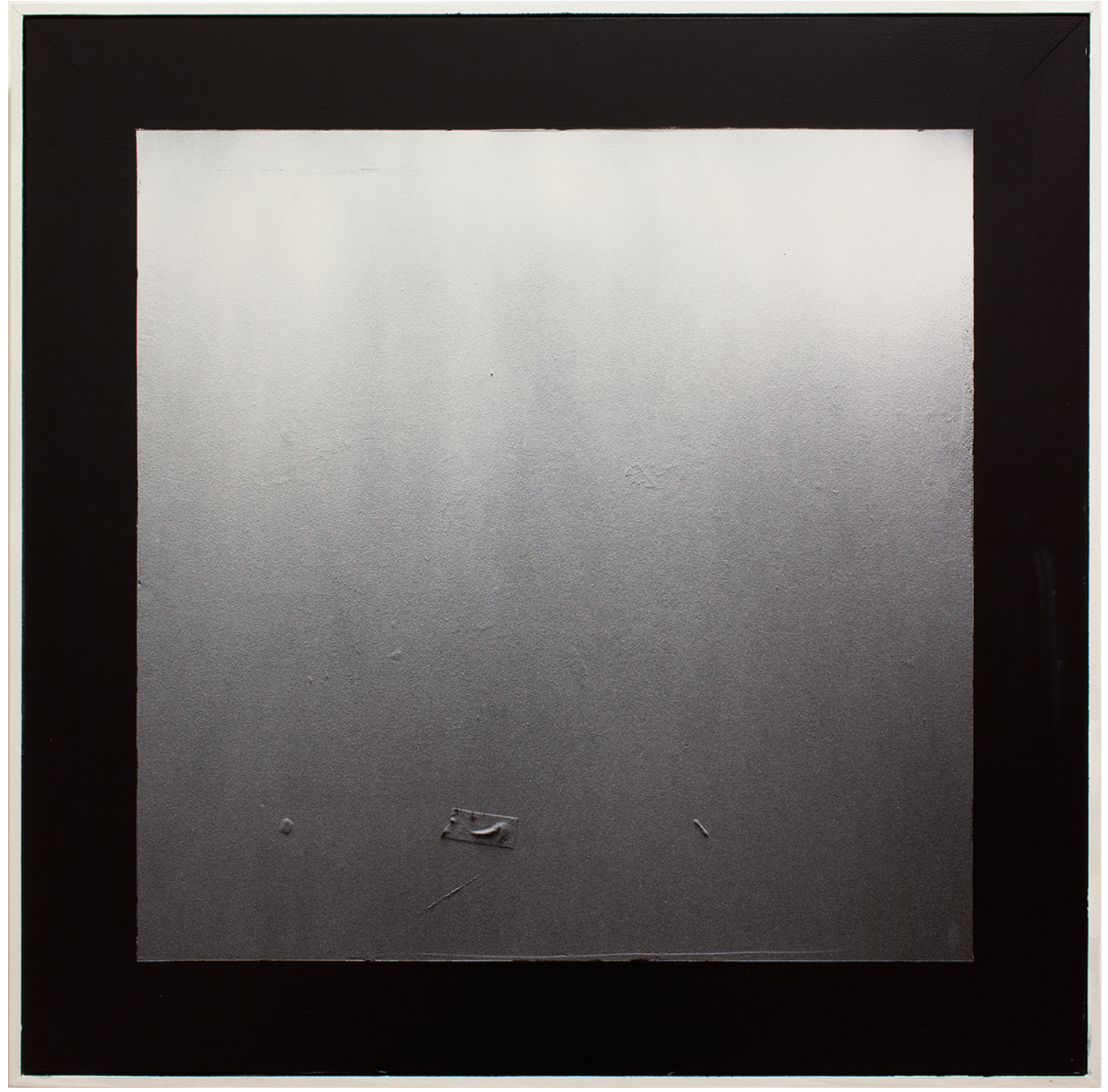

Figure 10

S. Charles Thompson

AMID I

Masking Tape, Spray Paint

26 " x 26"

2014 


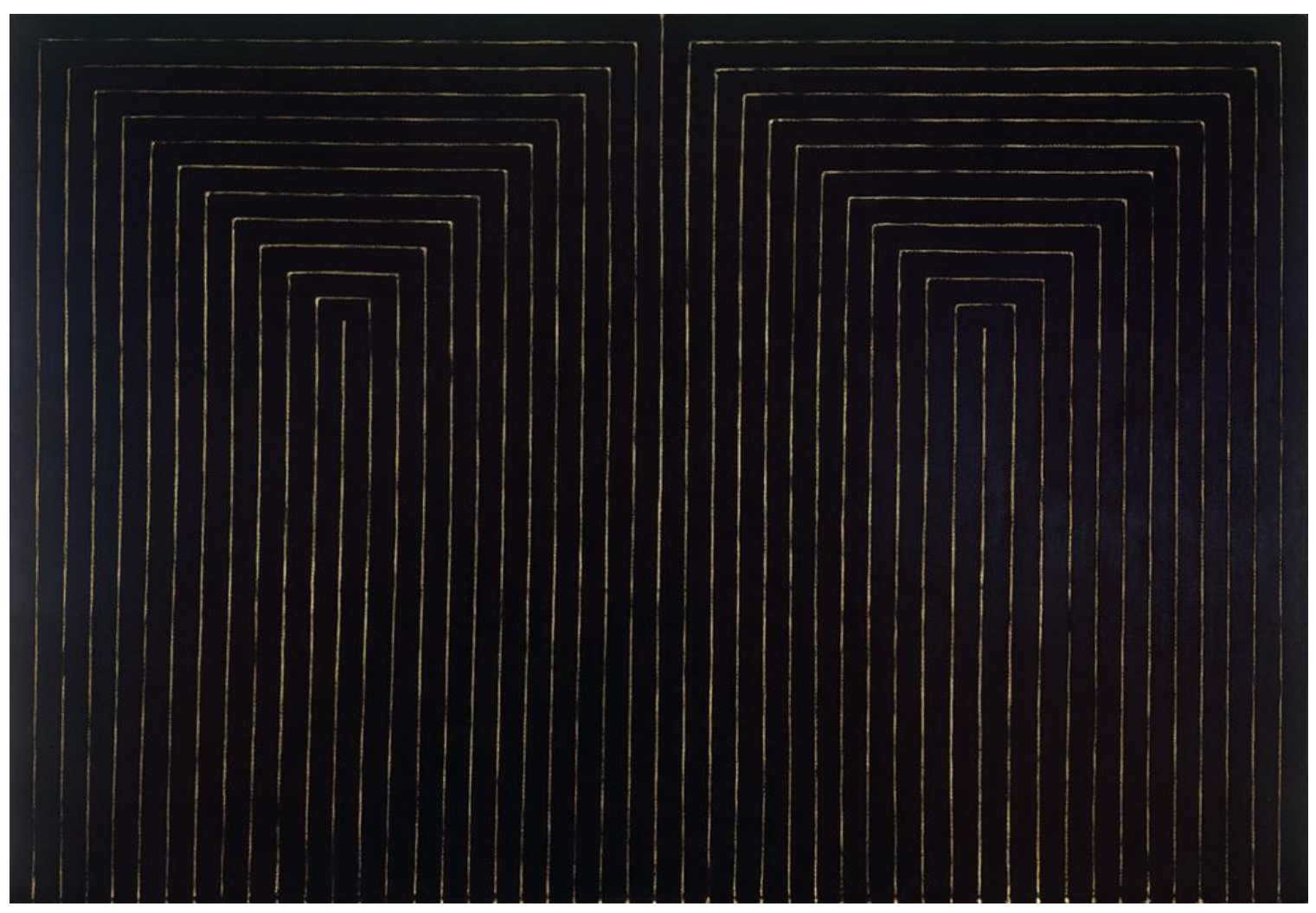

Figure 11

Frank Stella

The Marriage of Reason and Squalor II

Enamel on Canvas

7'6.75" x 11.75"

1959 


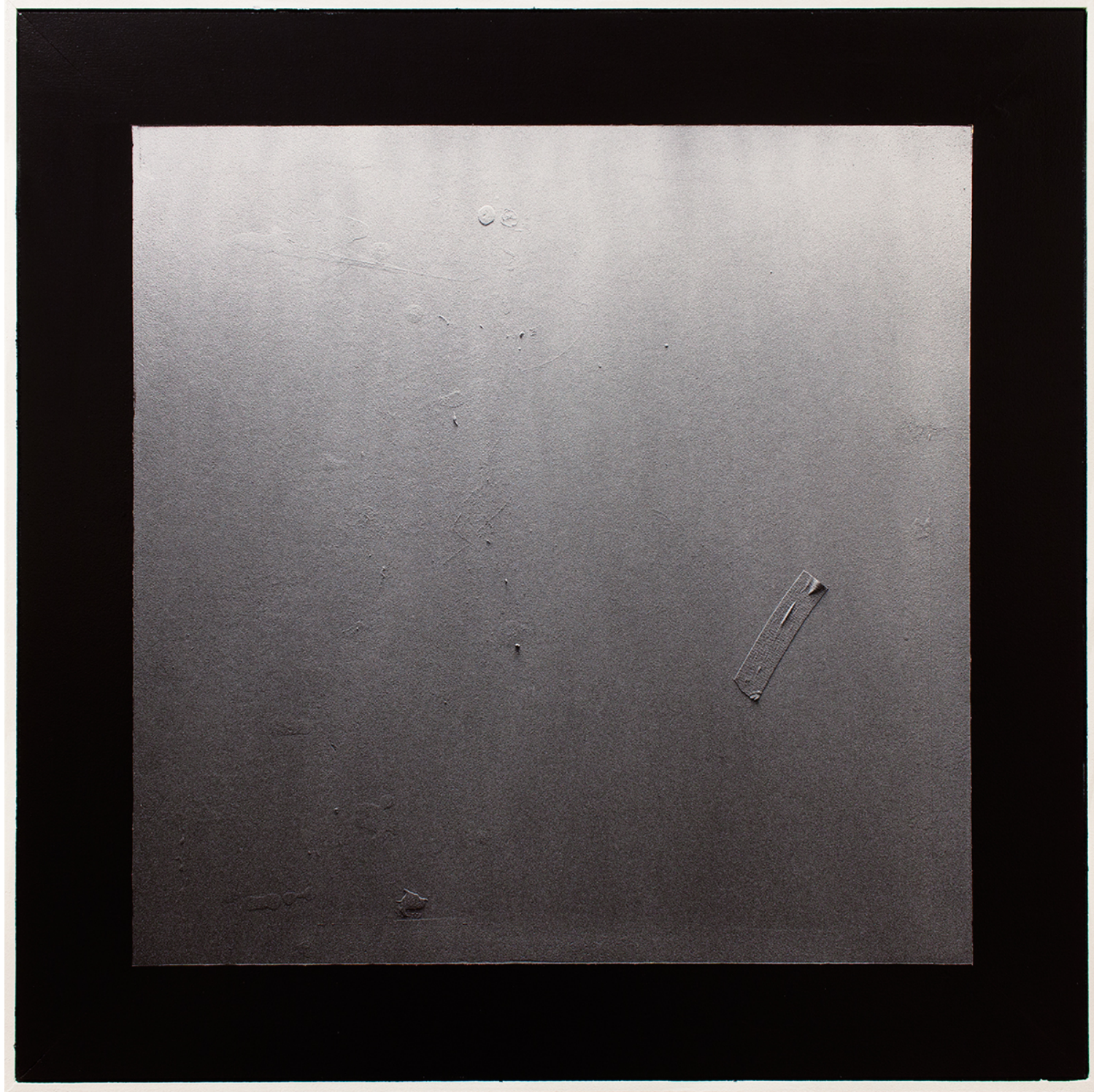

Figure 12

S. Charles Thompson AMID II

Masking Tape, Spray Paint

26 " x 26"

2014 


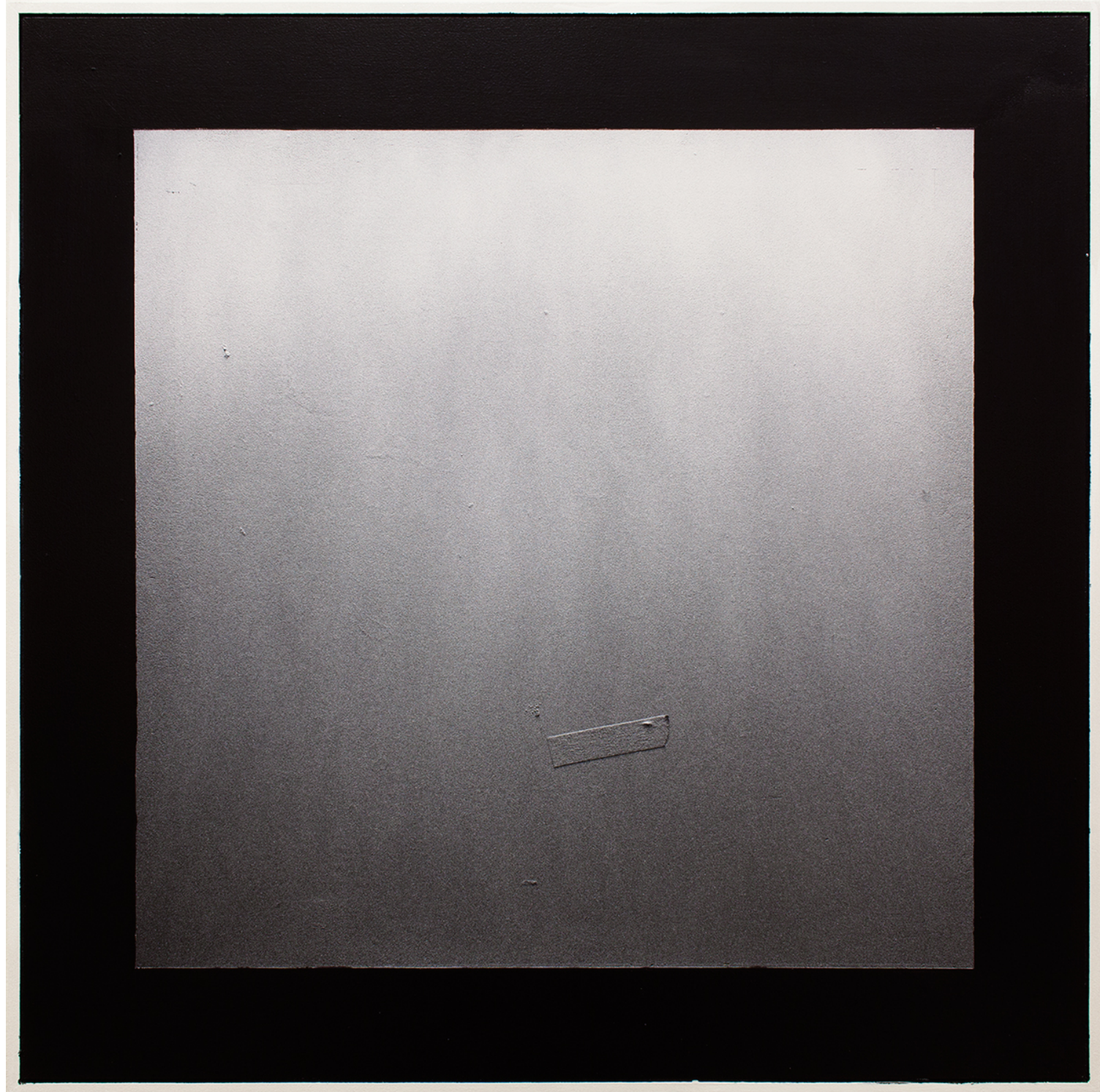

Figure 13

S. Charles Thompson AMID III

Masking Tape, Spray Paint 26 " x 26"

2014 


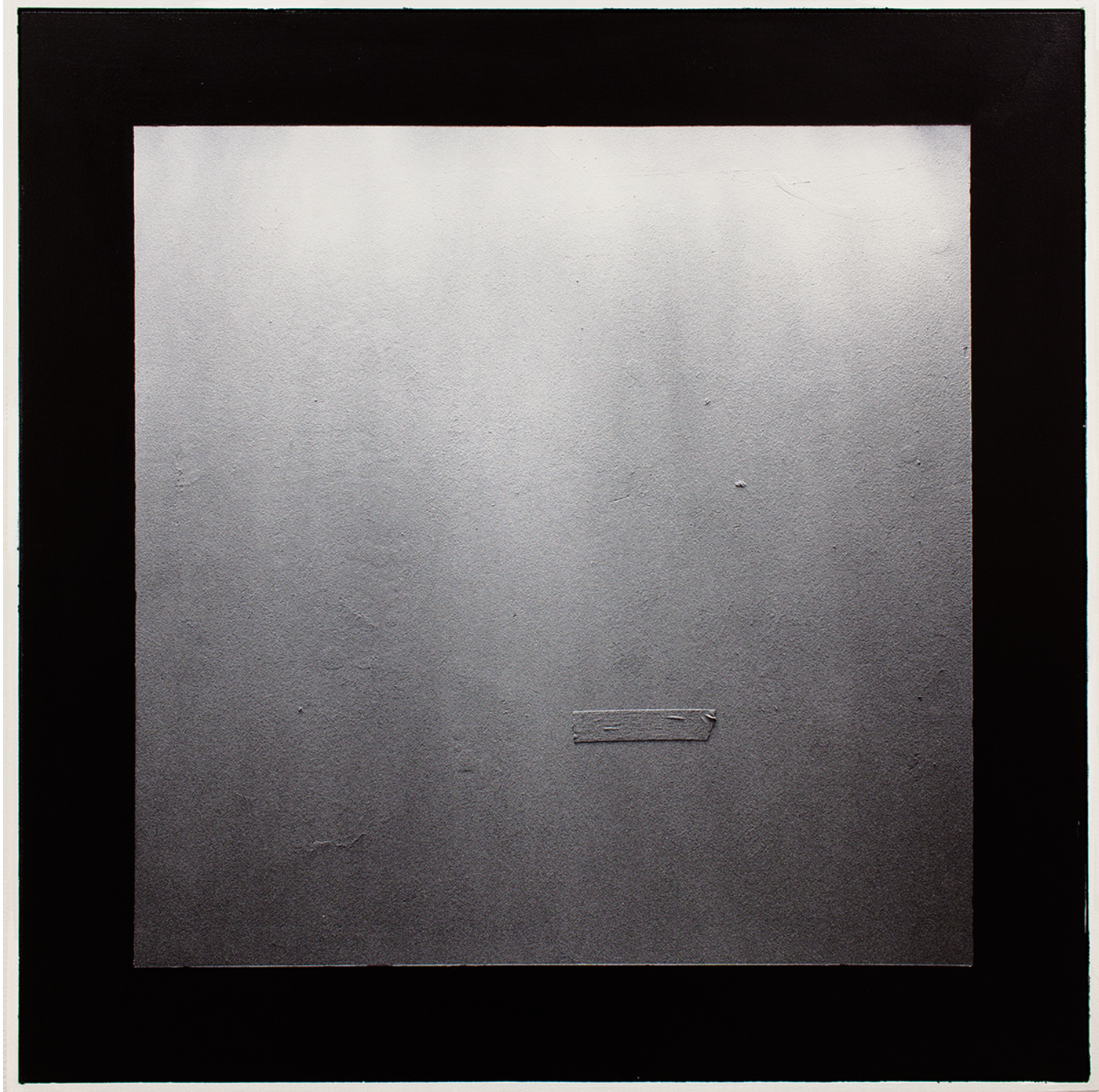

Figure 14

S. Charles Thompson AMID IV

Masking Tape, Spray Paint 26 " x 26"

2014 


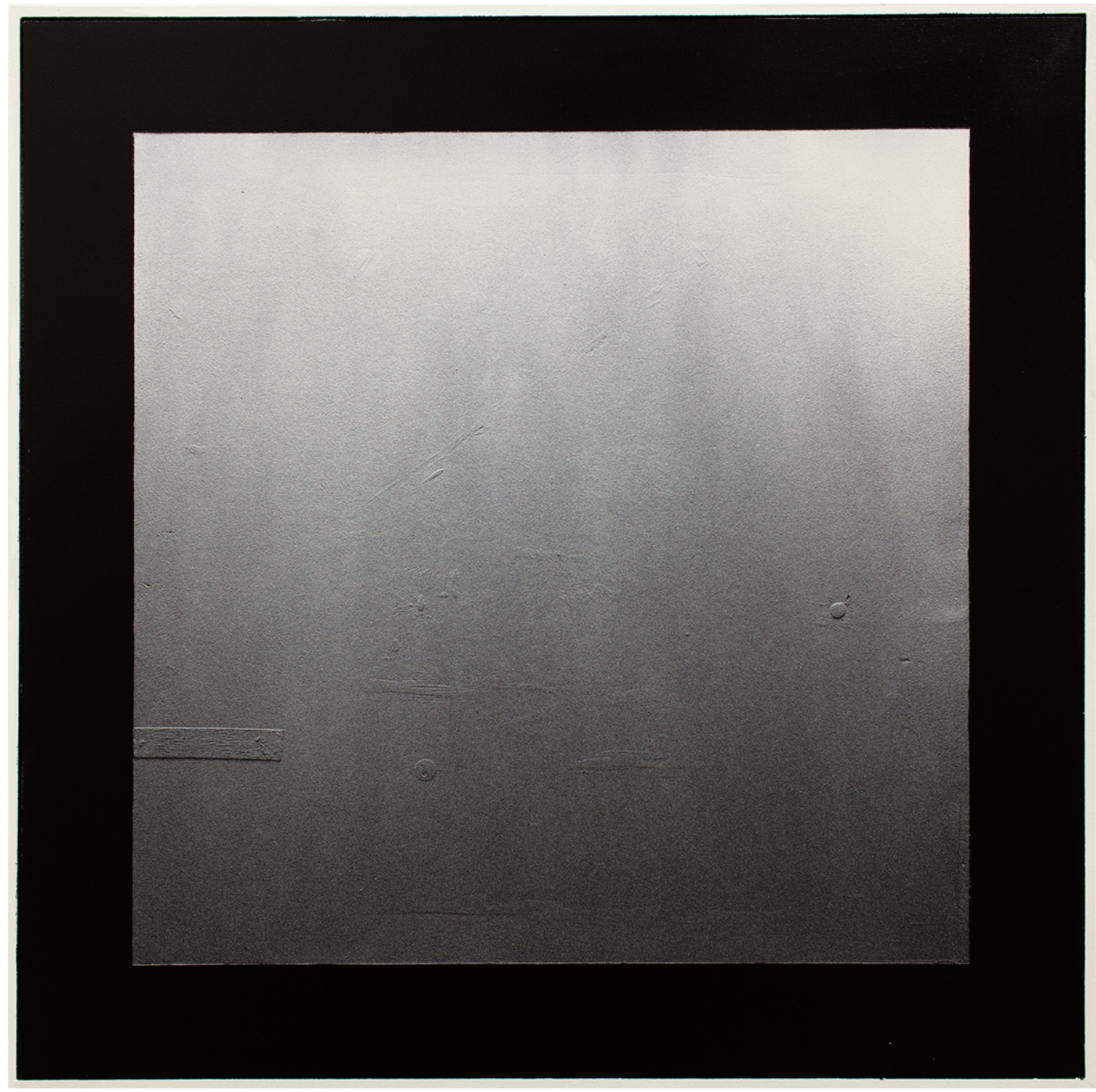

Figure 15

S. Charles Thompson

AMID $V$

Masking Tape, Spray Paint

26 " x 26"

2014 


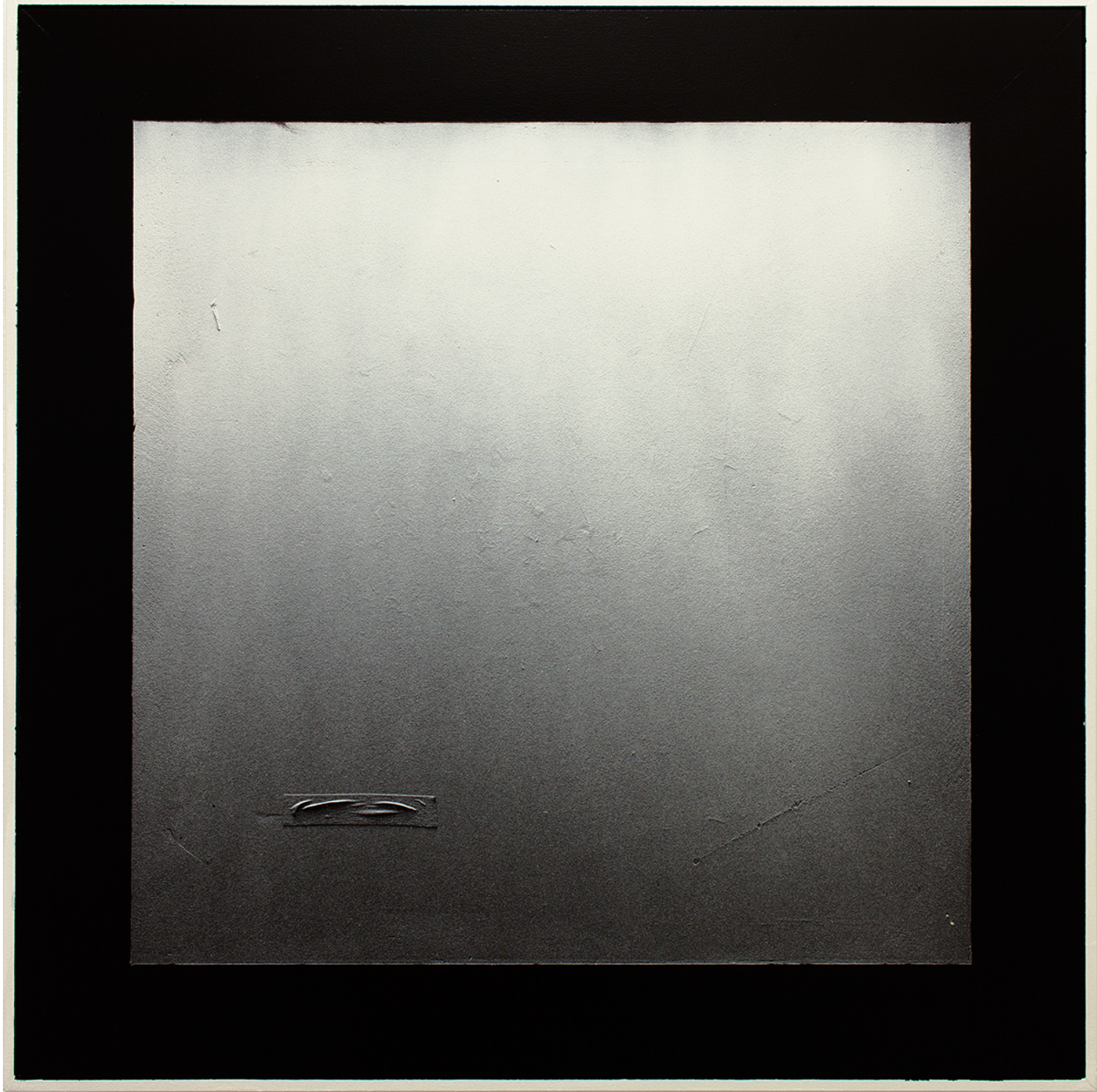

Figure 16

S. Charles Thompson AMID VI

Masking Tape, Spray Paint

26 " x 26 "

2014 


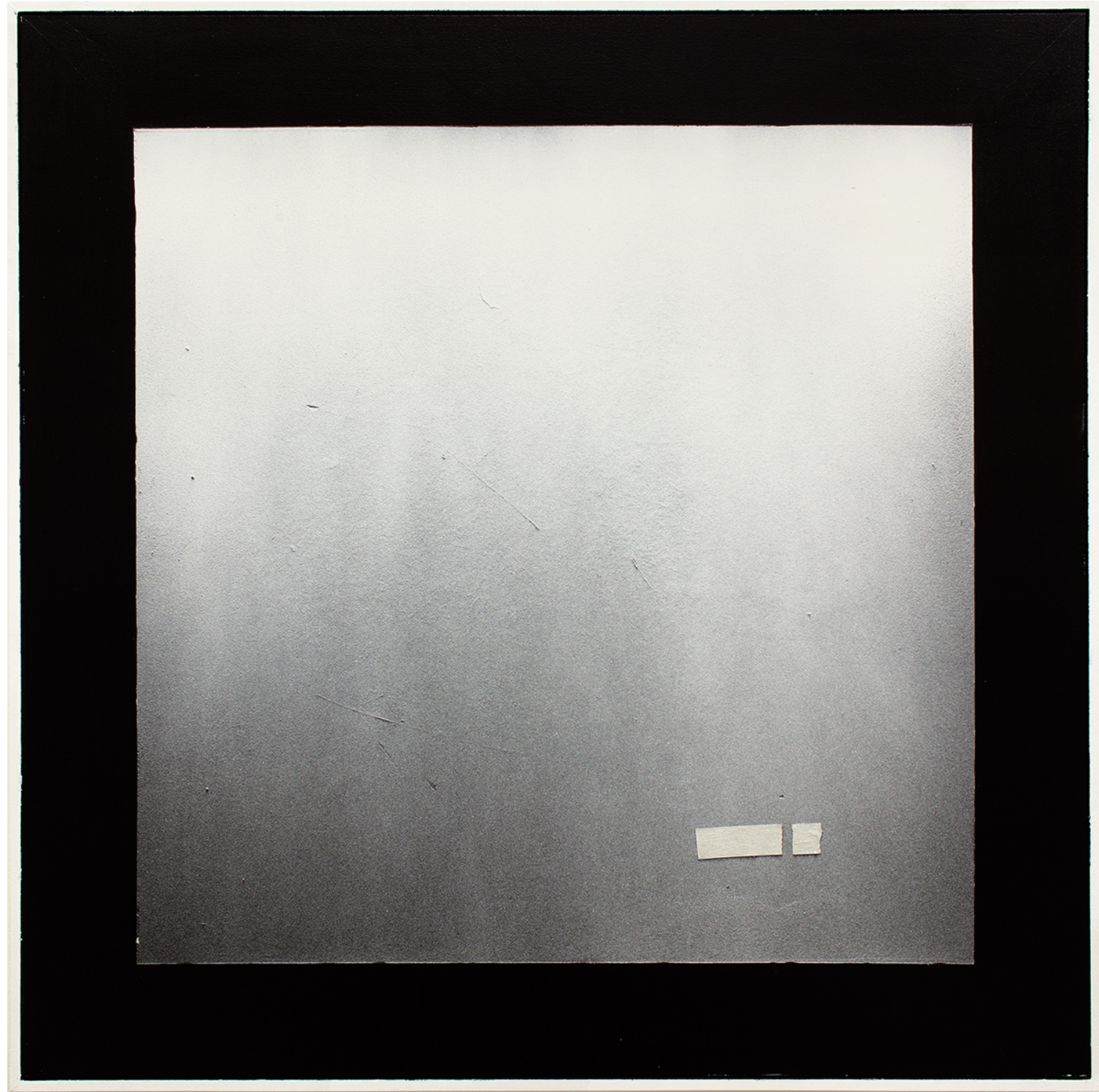

Figure 17

S. Charles Thompson

SHIFT II

Masking Tape, Spray Paint

26 " x 26"

2014 


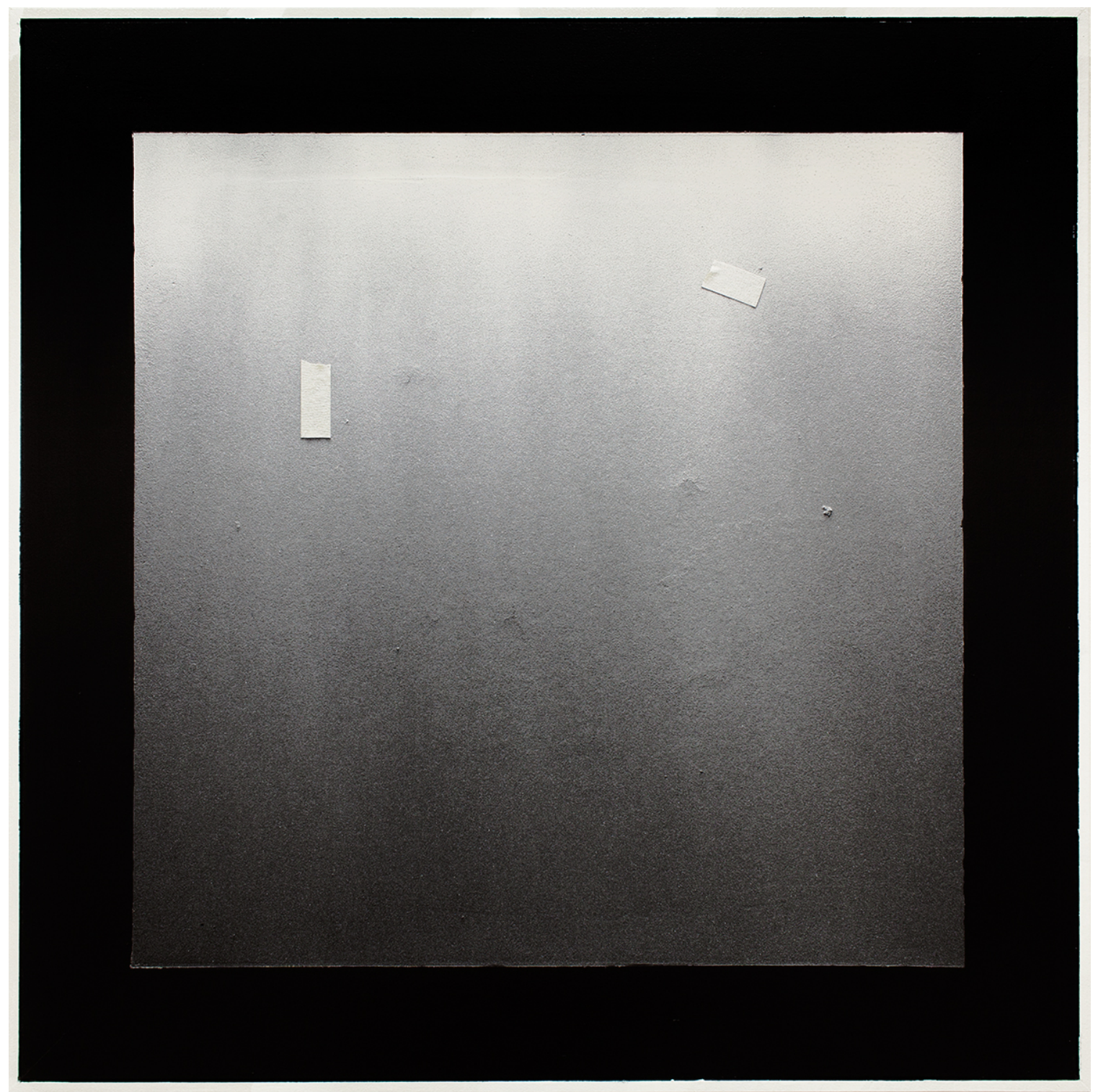

Figure 18

S. Charles Thompson

SHIFT III

Masking Tape, Spray Paint

26 " x 26"

2014 


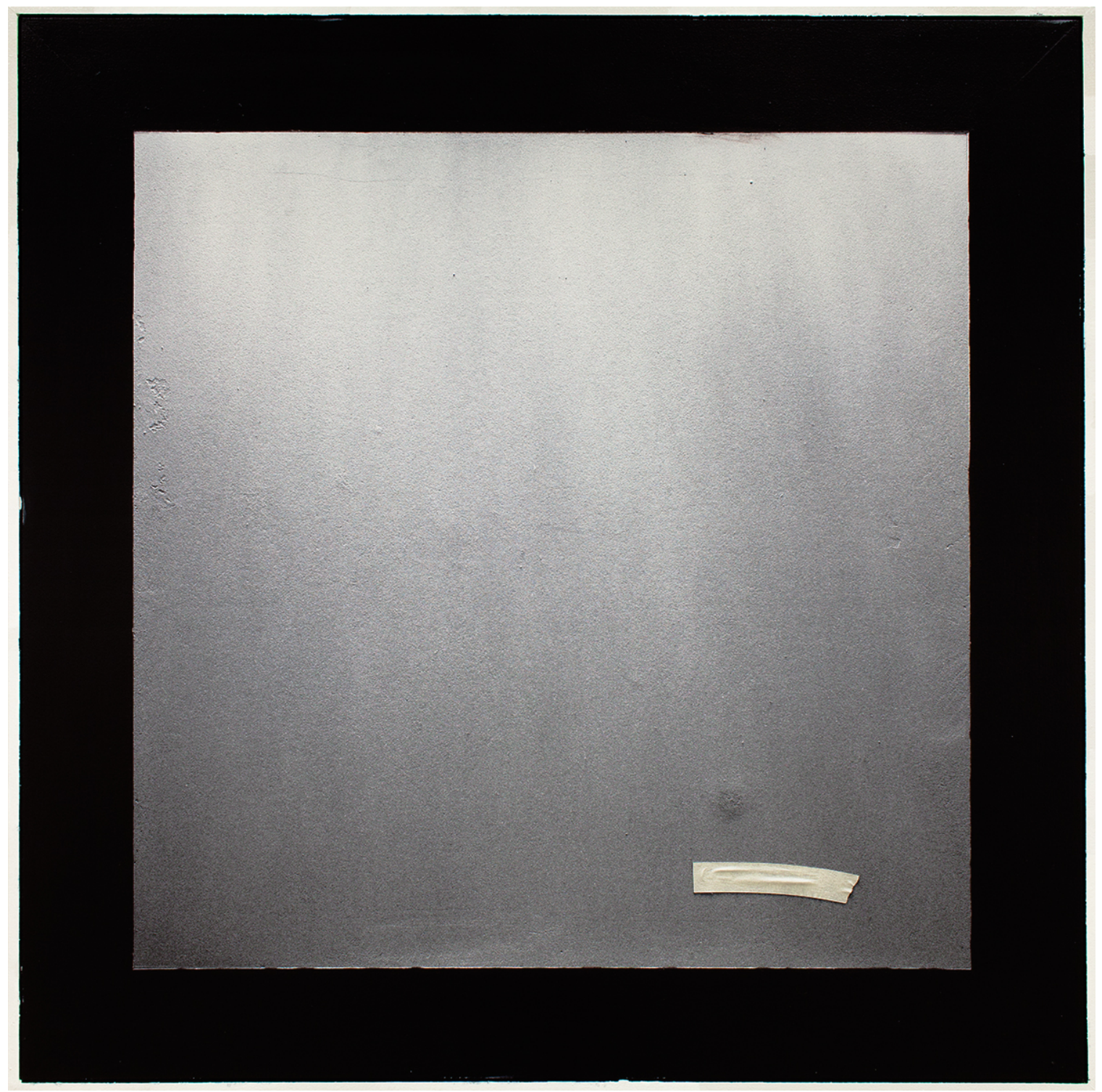

Figure 19

S. Charles Thompson

SHIFT IV

Masking Tape, Spray Paint

26 " x 26 "

2014 


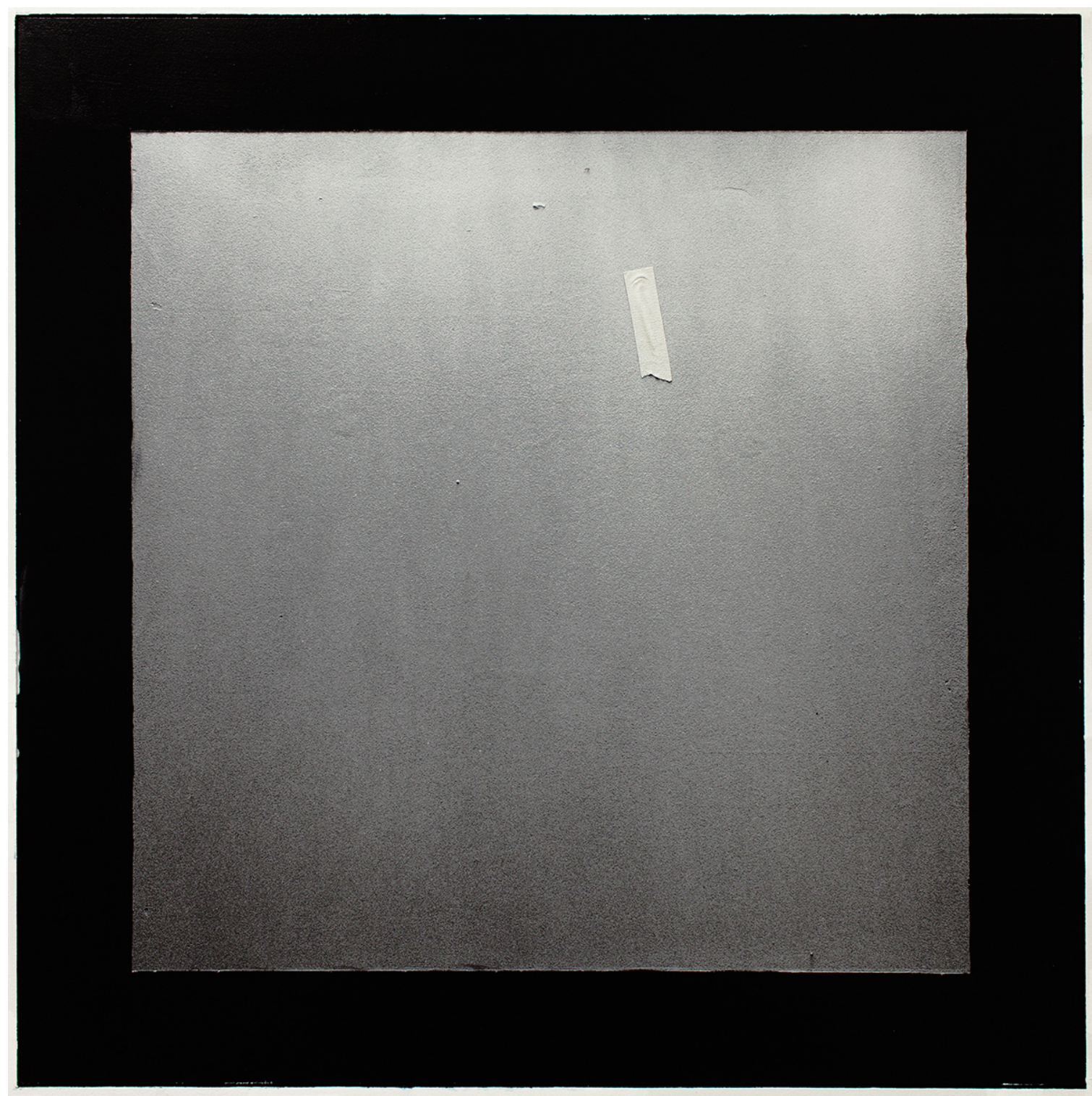

Figure 20

S. Charles Thompson

SHIFT V

Masking Tape, Spray Paint

26 " x 26"

2014 


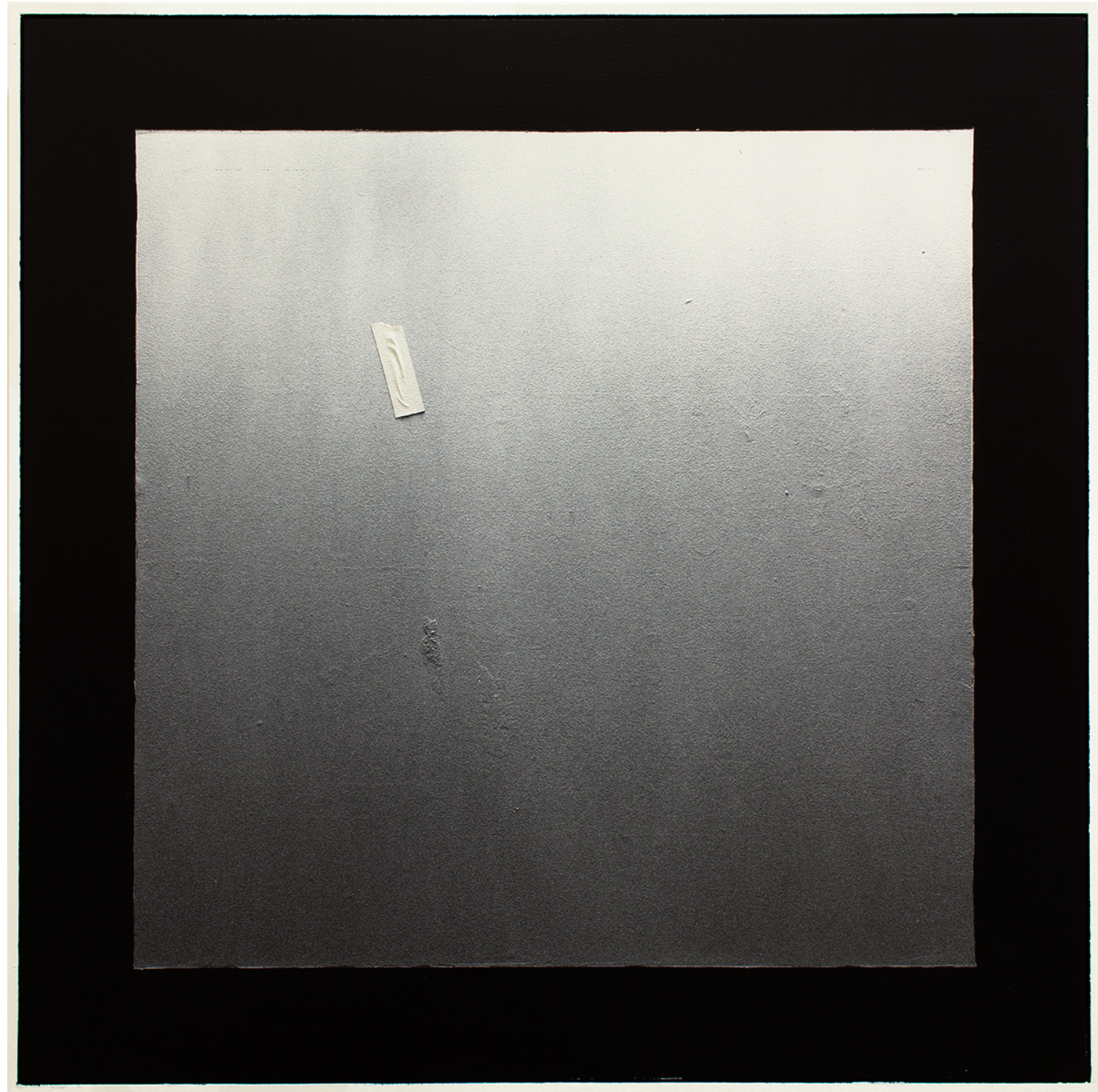

Figure 21

S. Charles Thompson

SHIFT VI

Masking Tape, Spray Paint

26 " x 26"

2014 


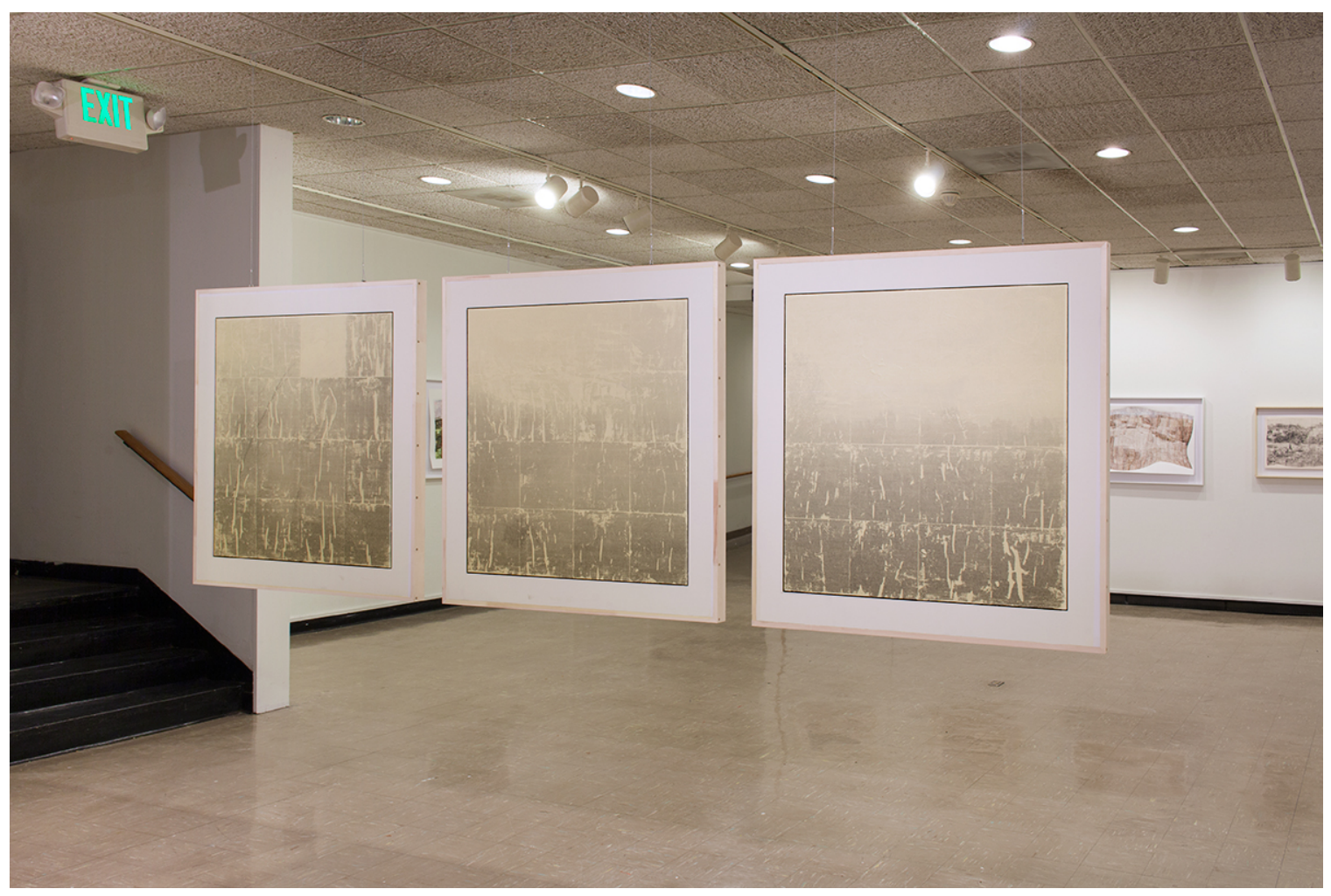

Figure 22 - S. Charles Thompson, Installation Shot I, 2014

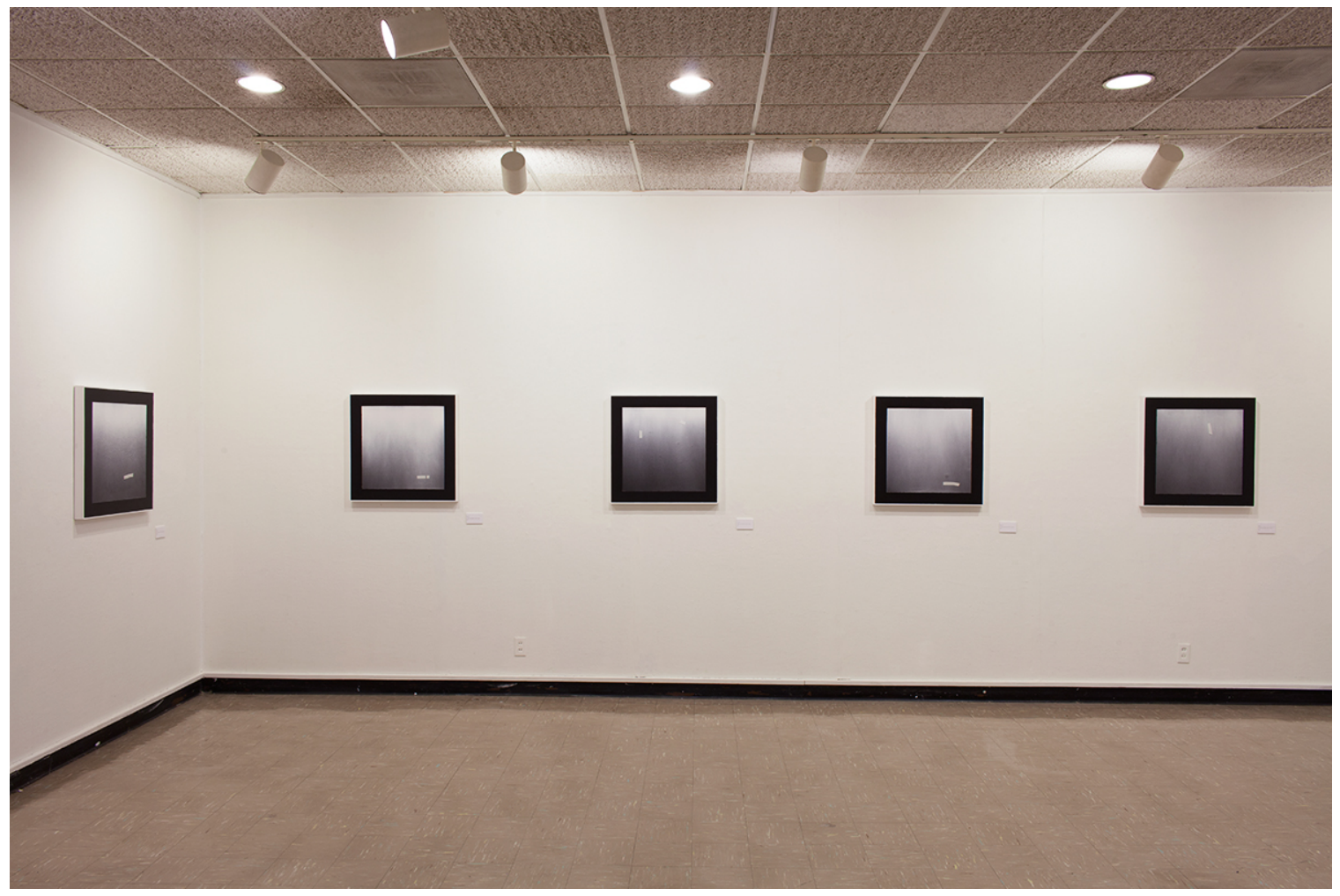

Figure 23 - S. Charles Thompson, Installation Shot II, 2014 


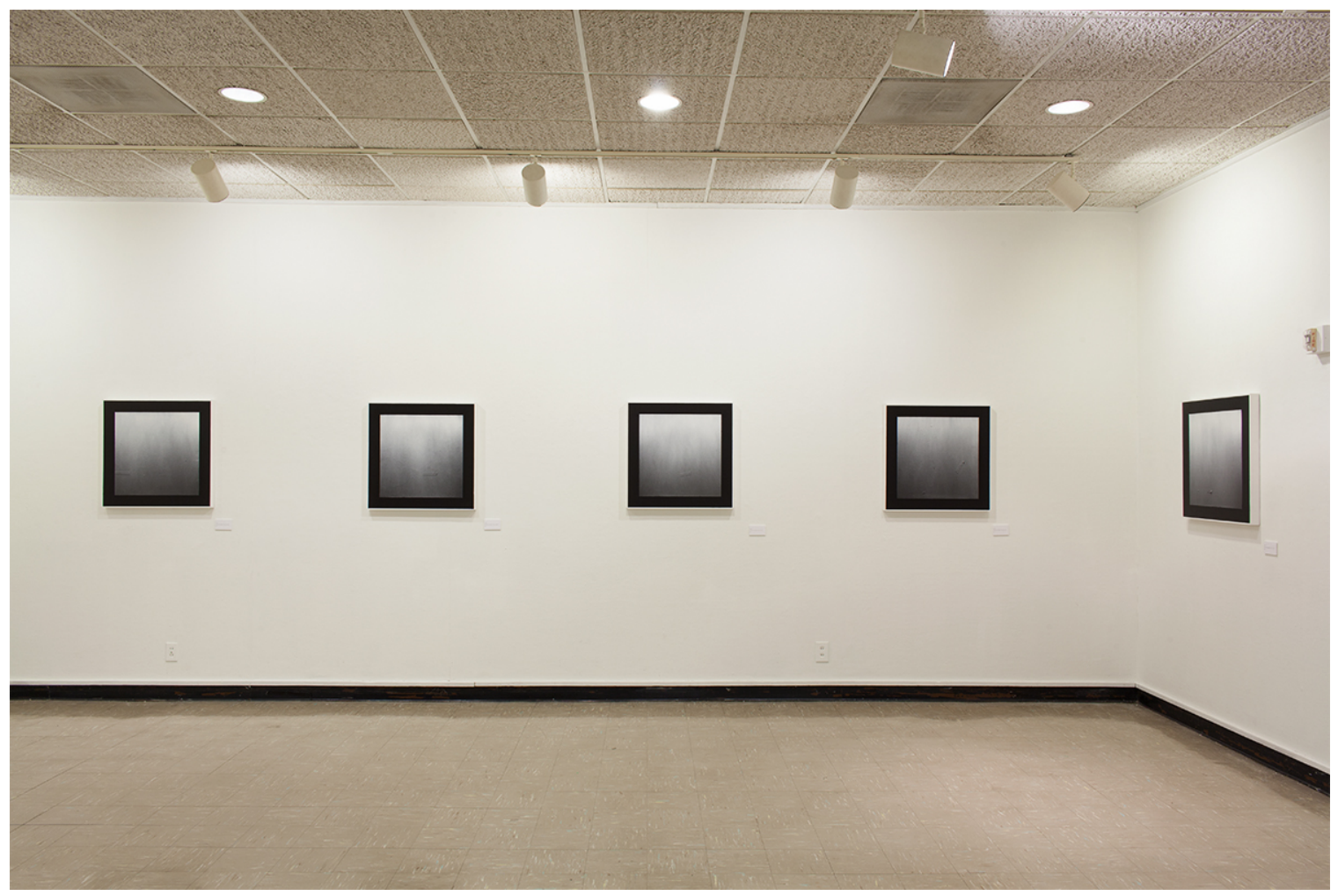

Figure 24 - S. Charles Thompson, Installation Shot III, 2014

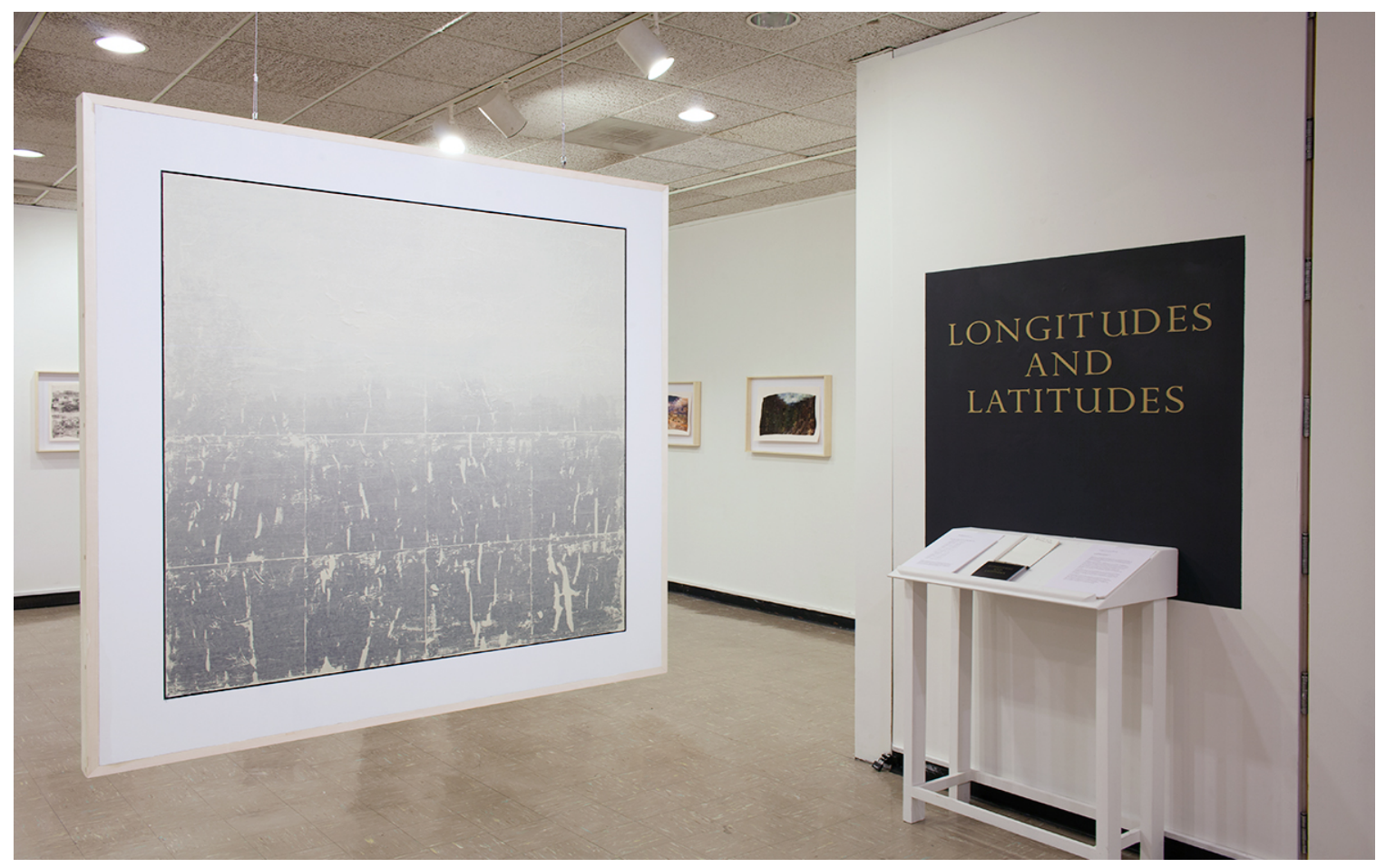

Figure 25 - S. Charles Thompson, Installation Shot IV, 2014 


\section{Bibliography}

Barthes, Roland. Camera Lucida: Reflections on Photography. Translated by Richard

Howard. Hill and Wang. New York, New York. 1980.

Carol Simpson and Bruice Henderson. Performance: Texts and Contexts. Longman. New York, New York. 1993.

Cave, Stephen. Immortality. Crown Publishers. New York, New York. 2012.

Cvoro, Uros. "The Present Body, The Absent Body, and the Formless". Art Journal. Vol. 61, No. 4 (Winter, 2002), pp. 54-63. accessed March 3, 2012. http://www.jstor.org/stable/778151.

Derrida, Jacques. Positions. Translated and Annotated by Alan Bass. The University of Chicago Press. New York, New York. 1981.

Eagleman, David. Sum: Forty tales for the Afterlives. Pantheon Books. New York, New York. 2009.

Ferris, Alison. "Disembodied Spirits: Spirit Photography and Rachel Whiteread's "Ghost"”. Art Journal. Vol. 62, No. 3 (Autumn, 2003), pp. 44-55. accessed March 3, 2013. http://www.jstor.org/stable/3558520.

Gill, Don. "Martha Rosler, 3 Works by Martha Rosler". Art Journal. Vol. 28, No. 2 (Fall - Winter, 2007). Pp. 49-50. Accessed May 12, 2013. http://www.jstor.org/stable/20358131.

Halpern, Daniel. Poetry. White Field. “The New Yorker”. December $17^{\text {th }}, 1979$.

Huyssen, Andreas. Twilight Memories: Marking Time in a Culture of Amnesia. Routledge. New York. 1995.

Karlin, Daniel. "Masterpieces of American Painting". Journal of American Studies. Vol. 18, No. 3 (Dec., 1984), pp. 447-449. accessed March 17, 2013. http://jstor.org/stable/27554502.

Kateb, George. Interviewed by Tyler Krupp and Rachel Stuart. Epicurean Thoughts on death. thinkingaloud.com. July 18, 2012. accessed March 17, 2014. http://www.youtube.com/watch?v=SjwEZG5OtoA.

Krauss, Rosalind. The Originality of the Avant-Garde and other Modernist Myths. MIT Press. New York, New York. 1985. 
Lacan, Jacques. The Four Fundamental Concepts of Psychoanalysis. The Seminar of Jacques Lacan book XI. Edited by Jacques-Alain Miller.

Translated by Alan Sheridan. W.W. Norton and Company. London. 1998.

Larson, Edward J. Summer of the Gods. The Scopes Trial and Americas Continuing Debate over Science and Religion. Harvard University Press. Cambridge, Mass. 1998.

Loos, Adolf. Ornament and Crime: Selected Essays. Translated by Michael Mitchell Ariadne Press. Riverside, California. 1997.

Lynne S. Crumrine and N. Ross Crumrine. "Service and Blood Sacrifice as Mediating Binary Oppositions: A Structural Analysis of Several Mayo Myths and Rituals". The Journal of AmericanFolklore. Vol. 83, No. 327 (Jan. Mar., 1970), pp. 69 - 76. accessed December 3, 2012. http://www.jstor.org/stable/538784.

Marwick, Arthur. The Arts in the West Since 1945. Oxford University Press. New York, New York. 2002.

Marzona, Daniel. Minimal Art. Taschen. Köln, Germany. 2004.

Milman, Miriam. The Illusions of Reality: Trompe-L'oeil Painting. Skira, Rizzoli Geneva, Switzerland. 1982.

O’Doherty, Brian. Inside the White Cube. Lapis Press. San Francisco. 1986.

Powell, Earl A. Forward. Five Centuries of Trompe l'oeil painting: Deceptions Illusions. Sybile Ebert-schifferer...[et al.\}. National gallery of Art. Washington, D. C. 2002.

Quinton, Anthony. "Burke on the Sublime and Beautiful”. Philosophy. Vol. 36, No. 136

(Jan., 1961), pp. 71-73. accessed March 12, 2014. http://www.jstor.org/stable/3748935.

Saenger, Elizabeth. "On Paintings and Propositions: A New Approach to Syntax in the Visual Arts". Leonardo. Vol. 26, No. 4 (1993), pp. 353-357 accessed May 12, 2013. http://www.jstor.org/stable/1575931.

Lucius Annaeus Seneca and Robin Campbell. Letters from a stoic. Penguin Books. London, England. 1969 
Tzu, Lao. Tao Te Ching: An All-New Translation. Translated by William Scott Wilson. Kodanasha International. Tokyo. 2010.

Whiting, Cécile. "Trompe l'oeil painting and the Counterfeit Civil War". The Art Bulletin. Vol. 79, No. 2 (Jun., 1997), pp. 251-268. accessed March 17, 2014. http://jstor.org/stable/3046245.

William, James. Understanding Poststructuralism. Acumen. Chesham. 2005.

Zimmerman, Marc. "Polarities and Contradictions: Theoretical Bases of the Marxist-Structuralist Encouncounter". New German Critique. No. 7 (Winter, 1976), pp. 69-90. accessed December 3, 2013. http://www.jstor.org/stable/487771.

Zupančič, Alenka. Ethics of the Real. Verso. London. 2000. 